\title{
Biomass Accumulation, Photosynthetic Traits and Root Development of Cotton as Affected by Irrigation and Nitrogen-Fertilization
}

\author{
Zongkui Chen ${ }^{1+}$, Xianping Tao ${ }^{1,2+}$, Aziz Khan ${ }^{3}$, Daniel K. Y. Tan ${ }^{4}$ and Honghai Luo ${ }^{1 *}$ \\ ${ }^{1}$ Key Laboratory of Oasis Eco-Agriculture, Xinjiang Production and Construction Group, College of Agriculture, Shihezi \\ University, Shihezi, China, ${ }^{2}$ Center of Agricultural Technique Extension of Manasi County, Manasi, China, ${ }^{3}$ Key Laboratory of \\ Plant Genetics and Breeding, College of Agriculture, Guangxi University, Nanning, China, ${ }^{4}$ Faculty of Science, Plant \\ Breeding Institute, Sydney Institute of Agriculture, School of Life and Environmental Sciences, The University of Sydney, \\ Sydney, NSW, Australia
}

OPEN ACCESS

Edited by:

Abraham J. Escobar-Gutiérrez, Institut National de la Recherche

Agronomique (INRA), France

Reviewed by:

Baris Uzilday,

Ege University, Turkey

Dirceu Mattos Jr.,

Instituto Agronômico de

Campinas (IAC), Brazil

*Correspondence:

Honghai Luo

luohonghai79@163.com

tThese authors have contributed

equally to this work.

Specialty section:

This article was submitted to

Crop and Product Physiology,

a section of the journal

Frontiers in Plant Science

Received: 03 November 2017

Accepted: 30 January 2018

Published: 15 February 2018

Citation:

Chen Z, Tao X, Khan A, Tan DKY and Luo $H$ (2018) Biomass Accumulation, Photosynthetic Traits and Root Development of Cotton as Affected by Irrigation

and Nitrogen-Fertilization.

Front. Plant Sci. 9:173.

doi: 10.3389/fpls.2018.00173
Limitations of soil water and nitrogen $(\mathrm{N})$ are factors which cause a substantial reduction in cotton (Gossypium hirsutum L.) yield, especially in an arid environment. Suitable management decisions like irrigation method and nitrogen fertilization are the key yield improvement technologies in cotton production systems. Therefore, we hypothesized that optimal water- $\mathrm{N}$ supply can increase cotton plant biomass accumulation by maintaining leaf photosynthetic capacity and improving root growth. An outdoor polyvinyl chloride (PVC) tube study was conducted to investigate the effects of two water- $\mathrm{N}$ application depths, i.e., $20 \mathrm{~cm}\left(\mathrm{H}_{20}\right)$ or $40 \mathrm{~cm}\left(\mathrm{H}_{40}\right)$ from soil surface and four water-N combinations [deficit irrigation $\left(W_{55}\right)$ and no N ( $\left.N_{0}\right)\left(W_{55} N_{0}\right), W_{55}$ and moderate $N\left(N_{1}\right)\left(W_{55} N_{1}\right)$, moderate irrigation $\left(W_{75}\right)$ and $\left.N_{0}\left(W_{75} N_{0}\right), W_{75} N_{1}\right]$ on the roots growth, leaf photosynthetic traits and dry mass accumulation of cotton crops. $\mathrm{H}_{20} \mathrm{~W}_{55} \mathrm{~N}_{1}$ combination increased total dry mass production by $29-82 \%$ and reproductive organs biomass by $47-101 \%$ compared with other counterparts. Root protective enzyme and nitrate reductase (NR) activity, potential quantum yield of photosystem (PS) ॥ $\left(F_{v} / F_{m}\right)$, PSIl quantum yield in the light $[\mathrm{Y}(\mathrm{II})]$ and electron transport rate of PSIl were significantly higher in $\mathrm{H}_{20} \mathrm{~W}_{55} \mathrm{~N}_{1}$ prior to 82 days after emergence. Root NR activity and protective enzyme were significantly correlated with chlorophyll, $F_{v} / F_{m}, Y(I I)$ and stomatal conductance. Hence, shallow irrigation $(20 \mathrm{~cm})$ with moderate irrigation and $\mathrm{N}$-fertilization application could increase cotton root NR activity and protective enzyme leading to enhance light capture and photochemical energy conversion of PSII before the full flowering stage. This enhanced photoassimilate to reproductive organs.

Keywords: cotton, fertigation, biomass, antioxidants, photosynthesis, root growth

Abbreviations: CAT, catalase; $\mathrm{Chl} a$ and $b$, chlorophyll $a$ and $b$; $C_{\mathrm{i}}$, intercellular $\mathrm{CO}_{2}$ concentration; DAE, days after emergence; ETR(II), electron transport rate of PSII; $F_{v} / F_{m}$, potential quantum yield of PSII; $g_{s}$, stomatal conductance; MDA, malondialdehyde; NR, nitrate reductase activity; $P_{\mathrm{n}}$ net photosynthetic rate; POD, peroxidase; Pro, proline; PS II, photosystem II; qN, non-photochemical quenching coefficient; qP, photochemical quenching coefficient; RLD, root length density; RMD, root mass density; RSD, root surface area density; SOD, superoxide dismutase; Y(II), PSII quantum yield in the light. 


\section{INTRODUCTION}

Water and nutrient availability has become a major limitation to photosynthate production of crop plants, especially in an arid environment (Lichtenthaler, 1996; Farooq et al., 2009). Moisture stress can decrease nutrient use efficiency and an inappropriate water-nutrient application can degrade soil physicochemical properties ( $\mathrm{pH}$, water permeability and nutrient status), resulting in yield loss (Vitousek et al., 1997; Hura et al., 2007). To improve crop performance, it is important to investigate the physiological processes involved in water-nutrient stress adaptation in plants. Therefore, crop management practices such as application of $\mathrm{N}$ fertilizer and alternative irrigation systems are often practiced (Farooq et al., 2009; Yahdjian et al., 2011).

Photosynthesis is the most essential process in the plant for growth and biomass production, thus it is the driving force for yield formation (Raines, 2011; Khan et al., 2017). However, low availability of water-nutrient can adversely influence photosynthesis (Lawlor and Cornic, 2002) and photosynthetic pigments (Makoto and Koike, 2007). Water or N stress can also cause a substantial reduction of photosynthetic enzymes (Evans, 1989; Flexas et al., 2006a), lead to disorganization of thylakoid membranes (Ladjal et al., 2000) and inhibition of photosystem activity (Lawlor and Cornic, 2002; Flexas et al., 2006a). Lower $\mathrm{CO}_{2}$ assimilation may lead to an imbalance between photochemical activity at PSII and electron requirement for photosynthesis (Hayashi et al., 2013; Yi et al., 2016). These changes can induce reactive oxygen species (ROS) production in leaves (Asada, 1999), which is potentially harmful to PSII reaction centers. This can also decrease the response level of the antioxidant enzymes to ROS (Reddy et al., 2004; Yi et al., 2016). Lower photochemical activity of photosystem is negatively associated with ETR. This can result in an inadequate supply of adenosine triphosphate (ATP) and or nicotinamide adenine dinucleotide phosphate $(\mathrm{NADPH})$ to reductive Calvin-Benson-Bassham (CBB) cycle that limited in ribulose-1,5-bisphosphate carboxylase/oxygenase (RuBP) regeneration (Tezara et al., 1999). Furthermore, this can adversely affect leaf photosynthesis, resulting in lower photosynthate production (Lawlor and Cornic, 2002).

Cotton roots are very sensitive to water or nutrient stress (Einsmann et al., 1999; Wasson et al., 2012), while the root morphological traits can be regulated by water-nutrient modes or rates (Wasson et al., 2012; Wu et al., 2013). Adequate water or $\mathrm{N}$ application can improve root distribution in the water or $\mathrm{N}$ applied zone in the soil, which increases water and $\mathrm{N}$ uptake resulting in higher accumulation of photosynthates (Blum, 2005; Wang et al., 2013; Xu et al., 2015; Zhang et al., 2017). Luo et al. (2014) suggested that cotton root vigor ensures the absorption of water- $\mathrm{N}$ and root vigor in the $40-120 \mathrm{~cm}$ soil layers and is closely associated with the $P_{\mathrm{n}}$. In addition, water or $\mathrm{N}$ stress negatively affects root physiological characteristics (nitrate reductase, root vigor and hormonal changes) resulting in decreased N uptake (Elvira et al., 2004; Blum, 2005; Luo et al., 2014). It is important to promote vertical distribution of roots for higher leaf photosynthetic capacity (Wu et al., 2013; Luo et al., 2014).
Cotton is the fifth largest fiber-producing plant worldwide. The total seed cotton yield in China accounts for approximately $30 \%$ of the worldwide cotton production. Xinjiang is the largest province of China which contributes about $60 \%$ of the cotton (China Cotton Fair Examination, 2012/2013). However, Xinjiang is an arid area in northwestern China; cotton production in the area mainly depends on irrigation. To achieve optimal yields, growers have increased water input (the agricultural water input increased by 20\% from 1965 to 2000) (Leiwen, 2005) and agricultural nutrient application (the nitrogen rate for the highest yield was up to $300 \mathrm{~kg} \mathrm{ha}^{-1}$ in Xinjiang, China, whereas the nitrogen rate for the highest cotton lint yield was $240 \mathrm{~kg} \mathrm{ha}^{-1}$ in the Yangtze River Valley) (Yang et al., 2011a). These practices have resulted in several problems, including nutrient imbalance in the soil (Ndabamenye et al., 2013), declining yields and quality (Loveys et al., 2000; Hu et al., 2011), and increasing soil salinization (Hoorn et al., 1993; Aragüés et al., 2014). It is important to identify the feasibility of optimal irrigation and fertilization to minimize yield reduction and environment pollution. Therefore, we hypothesized that optimizing water- $\mathrm{N}$ supply can increase cotton plant biomass accumulation by maintaining leaf photosynthetic capacity and enhancing root growth. The objectives of this were (1) to investigate the impacts of different water- $\mathrm{N}$ application depth and rate on cotton root morphological attributes and physiological activity, antioxidant enzyme activity, chlorophyll fluorescence, gas exchange parameters and dry matter production and (2) to determine the quantitative relationship among these factors in terms of improved plant performance. These data will help to develop management strategies for optimal cotton production in northwestern Xinjiang China.

\section{MATERIALS AND METHODS}

\section{Description of Experimental Site}

The field experiment was conducted in a rain-proof shed $(10 \mathrm{~m}$ length, $6 \mathrm{~m}$ width and $3 \mathrm{~m}$ height; the top of shed was covered of transparent polyethylene film, and it was only closed under rainfall conditions) at Shihezi University, Northwestern Xinjiang, China $\left(45^{\circ} 19^{\prime} \mathrm{N}, 74^{\circ} 56^{\prime} \mathrm{E}\right)$ during the 2012 growing season. The mean temperatures from April to October were 16.4, 12.5, 23.1, $27.2,21.2,18.3$, and $10.1^{\circ} \mathrm{C}$, respectively. The mean precipitation from April to October was 31.5, 25.5, 30.3, 17.8, 31.8, 15.8, and $10.8 \mathrm{~mm}$, respectively. Mean temperature and relative humidity were recorded by temperature and humidity recorder (TPJ20, Tuopu Instruments Ltd., Zhejiang, China) during the crop growing season. Seeds of (Xinluzao 33) cultivar were handplanted in each polyvinyl chloride $(\mathrm{PVC})$ tube $(30 \mathrm{~cm} \times 40 \mathrm{~cm}$; diameter $\times$ height). The bottom of each tube was covered with a wire mesh to hold the soil. A composite clay loam soil sample was collected from the field station; passed through a $2 \mathrm{~mm}$ sieve and then air dried. PVC tubes were filled up to $0.1-1.2 \mathrm{~m}$. Soil physical and chemical analysis produced the following characteristics: soil texture $(<0.01 \mathrm{~mm}$, purple clay loam) $54.0 \%, \mathrm{pH}=7.6,1.43 \mathrm{~g}$ $\mathrm{cm}^{-3}$ bulk density, EC $0.53 \mathrm{dS} \mathrm{m}^{-1}, 12.5 \mathrm{~g} \mathrm{~kg}^{-1}$ organic matter, $5.85 \mathrm{~g} \mathrm{~kg}^{-1}$ total $\mathrm{N}, 1.3 \mathrm{~g} \mathrm{~kg}^{-1}$ available $\mathrm{N}, 1.2 \mathrm{~g} \mathrm{~kg}^{-1}$ total $\mathrm{P}$, 
$3.54 \mathrm{mg} \mathrm{kg}^{-1}$ water $\mathrm{P}, 16.2 \mathrm{mg} \mathrm{kg}^{-1}$ available $\mathrm{P}, 1.77 \mathrm{~g} \mathrm{~kg}^{-1}$ total $\mathrm{K}, 195 \mathrm{mg} \mathrm{kg}^{-1}$ available K.

\section{Experimental Design and Field Management}

The experiment was laid out in a randomized complete block design with nine treatments as follows: two irrigation levels, i.e., deficit irrigation (irrigation level was maintained at $55 \pm 5 \%$ of field capacity, $\mathrm{W}_{55}$ ) and adequate irrigation (irrigation level was maintained at $75 \pm 5 \%$ of field capacity, $\left.W_{75}\right)$; two $N$ fertilizer rate was no nitrogen $\left(\mathrm{N}_{0}\right.$, no nitrogen application) and moderate $\mathrm{N}\left(0.216 \mathrm{~N} \mathrm{~g} \mathrm{~kg}^{-1}\right.$ dry soil, $\left.\mathrm{N}_{1}\right)$ and two application depths of $20 \mathrm{~cm}\left(\mathrm{H}_{20}\right)$ or $40 \mathrm{~cm}\left(\mathrm{H}_{40}\right)$ from soil surface. $\mathrm{CK}$ (check or control), irrigation and $\mathrm{N}$ fertilizer on the depth of $0 \mathrm{~cm}$ from soil surface, irrigation and $\mathrm{N}$ fertilizer application rate, respectively, was the same as $\mathrm{W}_{75}$ and $\mathrm{N}_{1}$ (irrigation and fertilizer management methods widely used in the local area); irrigation and fertilizer management level or depth were used in the following combinations: (1) $\mathrm{CK}$, (2) $\mathrm{H}_{20} \mathrm{~W}_{55} \mathrm{~N}_{0}$, (3) $\mathrm{H}_{20} \mathrm{~W}_{55} \mathrm{~N}_{1}$, (4) $\mathrm{H}_{20} \mathrm{~W}_{75} \mathrm{~N}_{0}$, (5) $\mathrm{H}_{20} \mathrm{~W}_{75} \mathrm{~N}_{1}$, (6) $\mathrm{H}_{40} \mathrm{~W}_{55} \mathrm{~N}_{0}$, (7) $\mathrm{H}_{40} \mathrm{~W}_{75} \mathrm{~N}_{1}$, (8) $\mathrm{H}_{40} \mathrm{~W}_{75} \mathrm{~N}_{0}$, (9) $\mathrm{H}_{40} \mathrm{~W}_{75} \mathrm{~N}_{1}$.

Irrigation and $\mathrm{N}$ application depth were assessed using a drainage tube (diameter $2 \mathrm{~cm}$; length $20 \mathrm{~cm}$ in the $\mathrm{H}_{20}$ and length $40 \mathrm{~cm}$ in the $\mathrm{H}_{40}$ ), while drip irrigation was supplemented to control (CK). This system is widely used in Xinjiang province. $\mathrm{N}$ fertilizer was applied at the rate of $0 \mathrm{~g}$ tube $^{-1}\left(\mathrm{~N}_{0}\right)$ and $2.76 \mathrm{~g}$ tube $^{-1}\left(\mathrm{~N}_{1}\right)$ treatment. Nitrogen was applied with the ratio of basal fertilizer to topdressing of 1:4. Phosphorus and potassium were supplemented as basal fertilization. Nitrogen in the form of Urea $\left[\mathrm{CO}\left(\mathrm{NH}_{2}\right)_{2}, 46.0 \% \mathrm{~N}\right]$ at the rate of $13.8 \mathrm{~g}$ per tube was used, while $18 \mathrm{~g}$ of monopotassium phosphate $\left[\left(\mathrm{KH}_{2} \mathrm{PO}_{4}\right)\right.$ $52.0 \% \mathrm{P}_{2} \mathrm{O}_{5}$ and $35.4 \% \mathrm{~K}_{2} \mathrm{O}$ ] was used per tube for the application of aforementioned amounts of $\mathrm{P}_{2} \mathrm{O}_{5}$ and $\mathrm{K}_{2} \mathrm{O}$. Topdressing $\mathrm{N}$ fertilizers were applied in equal amounts at 55, 70, 85, and 100 days after planting.

Four seeds were sown at a depth of $3 \mathrm{~cm}$ in each tube on 21 April. The seeds were spaced $10 \mathrm{~cm}$ apart in one direction and $20 \mathrm{~cm}$ apart in the other. Soil water content was measured after each 3-day interval using Watermarks (Soil Moisture Meter, IRROMETER COMPANY, Inc., NE, United States) at 20, 40, and $60 \mathrm{~cm}$ of the soil depth. The Watermarks were installed in each treatment of three replicates in order to indicate the soil water variation. Direct irrigation method was employed for $\mathrm{H}_{20}$ and $\mathrm{H}_{40}$ treatment to the required depth, while drip irrigation system was supplemented to $\mathrm{CK}$ treatment. Drip irrigations systems (Beijing Lvyuan Inc., China) were installed on the top of each tube and one emitter per tube was fixed. The irrigation rates were monitored using both water meter and switch ball valve. The tops of the tube were covered with a polyethylene film to reduce water loss through evaporation. Plants were thinned 15 days after planting to the desired population. In addition, gas exchange, chlorophyll fluorescence, extraction of chlorophyll and protective enzymes in the leaves from the top was performed six times, once every 10 days from 52 DAE to 102 DAE. Protective enzymes and root morphology parameters were measured at 82 and $102 \mathrm{DAE}$, respectively. Roots less than $5 \mathrm{~mm}$ were selected for measuring protective enzymes in the root. Shoot and root samples for MDA contents, antioxidant enzyme activities, free proline content and nitrate reductase were put in a disposable ziplock bag and stored at $-80^{\circ} \mathrm{C}$. To extract enzymes to test for activity, the samples were put in $8 \mathrm{~mL}$ container and then ground using a freezing

TABLE 1 | The change in leaf biomass ( $\mathrm{g} \mathrm{plant}^{-1}$ ), stem biomass ( $\mathrm{g}$ plant ${ }^{-1}$ ), square and boll biomass (g plant $\left.{ }^{-1}\right)$, total aboveground biomass $\left(\mathrm{g}\right.$ plant $\left.{ }^{-1}\right)$, root biomass (g plant ${ }^{-1}$ ), total biomass ( $\mathrm{g}$ plant ${ }^{-1}$ ), root shoot ratio of cotton plant in coupling of irrigation depth and water-nitrogen application rate.

\begin{tabular}{|c|c|c|c|c|c|c|c|}
\hline Treatment & Leaf biomass & Stem biomass & $\begin{array}{l}\text { Square and boll } \\
\text { biomass }\end{array}$ & $\begin{array}{c}\text { Total aboveground } \\
\text { biomass }\end{array}$ & Root biomass & Total biomass & $\begin{array}{l}\text { Root shoot } \\
\text { ratio }\end{array}$ \\
\hline CK & $11.96 \pm 0.15^{b}$ & $9.42 \pm 0.07^{b}$ & $17.29 \pm 0.39^{b}$ & $38.67 \pm 0.31^{b}$ & $3.0 \pm 1.44^{\mathrm{C}}$ & $41.66 \pm 1.3^{b}$ & $0.08 \pm 0.04^{e}$ \\
\hline $\mathrm{H}_{20} \mathrm{~W}_{55} \mathrm{~N}_{0}$ & $7.78 \pm 0.18^{d}$ & $4.66 \pm 0.14^{f}$ & $12.6 \pm 0.12^{\mathrm{g}}$ & $25.04 \pm 0.249$ & $4.46 \pm 0.38^{b}$ & $29.5 \pm 0.51^{e}$ & $0.18 \pm 0.01^{b}$ \\
\hline $\mathrm{H}_{20} \mathrm{~W}_{55} \mathrm{~N}_{1}$ & $7.19 \pm 0.05^{\mathrm{e}}$ & $5.61 \pm 0.15^{\mathrm{e}}$ & $13.26 \pm 0.13^{f}$ & $26.06 \pm 0.23^{f}$ & $4.12 \pm 0.89^{b c}$ & $30.18 \pm 0.89^{e}$ & $0.16 \pm 0.03^{c}$ \\
\hline $\mathrm{H}_{20} \mathrm{~W}_{75} \mathrm{~N}_{0}$ & $9.64 \pm 0.91^{\mathrm{c}}$ & $7.44 \pm 0.94^{\mathrm{C}}$ & $15.94 \pm 0.26^{c}$ & $33.02 \pm 0.3^{c}$ & $3.51 \pm 0.59^{b c}$ & $36.53 \pm 0.33^{c}$ & $0.11 \pm 0.02^{d}$ \\
\hline $\mathrm{H}_{20} \mathrm{~W}_{75} \mathrm{~N}_{1}$ & $13.4 \pm 0.17^{a}$ & $12.08 \pm 0.07^{a}$ & $25.35 \pm 0.32^{a}$ & $50.83 \pm 0.11^{a}$ & $2.92 \pm 0.6^{c}$ & $53.75 \pm 0.64^{a}$ & $0.06 \pm 0.01^{f}$ \\
\hline $\mathrm{H}_{40} \mathrm{~W}_{55} \mathrm{~N}_{0}$ & $6.11 \pm 0.23^{f}$ & $4.16 \pm 0.15^{g}$ & $8.7 \pm 0.05^{i}$ & $18.97 \pm 0.14^{i}$ & $5.03 \pm 0.71^{a}$ & $24 \pm 0.85^{f}$ & $0.27 \pm 0.04^{a}$ \\
\hline $\mathrm{H}_{40} \mathrm{~W}_{55} \mathrm{~N}_{1}$ & $7.11 \pm 1.02^{\mathrm{e}}$ & $5.35 \pm 0.98^{\mathrm{e}}$ & $11.9 \pm 0.11^{\mathrm{h}}$ & $24.36 \pm 0.2^{h}$ & $4.61 \pm 0.23^{b}$ & $28.97 \pm 0.38^{e}$ & $0.19 \pm 0.01^{b}$ \\
\hline $\mathrm{H}_{40} \mathrm{~W}_{75} \mathrm{~N}_{0}$ & $7.67 \pm 0.42^{\mathrm{e}}$ & $6.32 \pm 0.47^{d}$ & $14.3 \pm 0.17^{e}$ & $28.29 \pm 0.11^{\mathrm{e}}$ & $4.11 \pm 0.75^{\mathrm{bc}}$ & $32.4 \pm 0.64^{d}$ & $0.15 \pm 0.03^{b c}$ \\
\hline $\mathrm{H}_{40} \mathrm{~W}_{75} \mathrm{~N}_{1}$ & $7.56 \pm 0.14^{e}$ & $6.65 \pm 0.24^{\mathrm{cd}}$ & $15.44 \pm 0.03^{d}$ & $29.65 \pm 0.1^{d}$ & $3.51 \pm 0.44^{b c}$ & $33.15 \pm 0.45^{d}$ & $0.12 \pm 0.01^{\mathrm{cd}}$ \\
\hline $\mathrm{H}$ & $* *$ & $* *$ & $* *$ & $* *$ & $*$ & $* *$ & $* *$ \\
\hline W & $* *$ & $* *$ & $* *$ & $* *$ & $*$ & $* *$ & $* *$ \\
\hline $\mathrm{N}$ & $* *$ & $* *$ & $* *$ & $* *$ & ns & $* *$ & $* *$ \\
\hline $\mathrm{H} \times W$ & $* *$ & $* *$ & $* *$ & $* *$ & ns & ns & $* *$ \\
\hline $\mathrm{H} \times \mathrm{N}$ & $* *$ & $* *$ & $* *$ & $* *$ & ns & ns & $* *$ \\
\hline $\mathrm{W} \times \mathrm{N}$ & $* *$ & $* *$ & $* *$ & $* *$ & $\mathrm{~ns}$ & ns & $* *$ \\
\hline $\mathrm{H} \times \mathrm{W} \times \mathrm{N}$ & $* *$ & $* *$ & $* *$ & $* *$ & ns & $*$ & $* *$ \\
\hline
\end{tabular}

Data are mean $\pm S E$, different letters indicate a significant difference $(p<0.05)$ among the treatments. **, *, and ns indicate extremely significant differences $(p<0.01)$, significant $(p<0.05)$ and no significant difference $(p>0.05)$, among watered depth, watered rate and nitrogen application rate within an irrigation treatment. $H_{20}$,

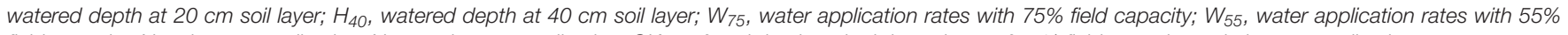
field capacity; $N_{1}$, nitrogen application; $N_{0}$, no nitrogen application; CK, surface irrigation, the irrigated rate of $75 \%$ field capacity and nitrogen application. 


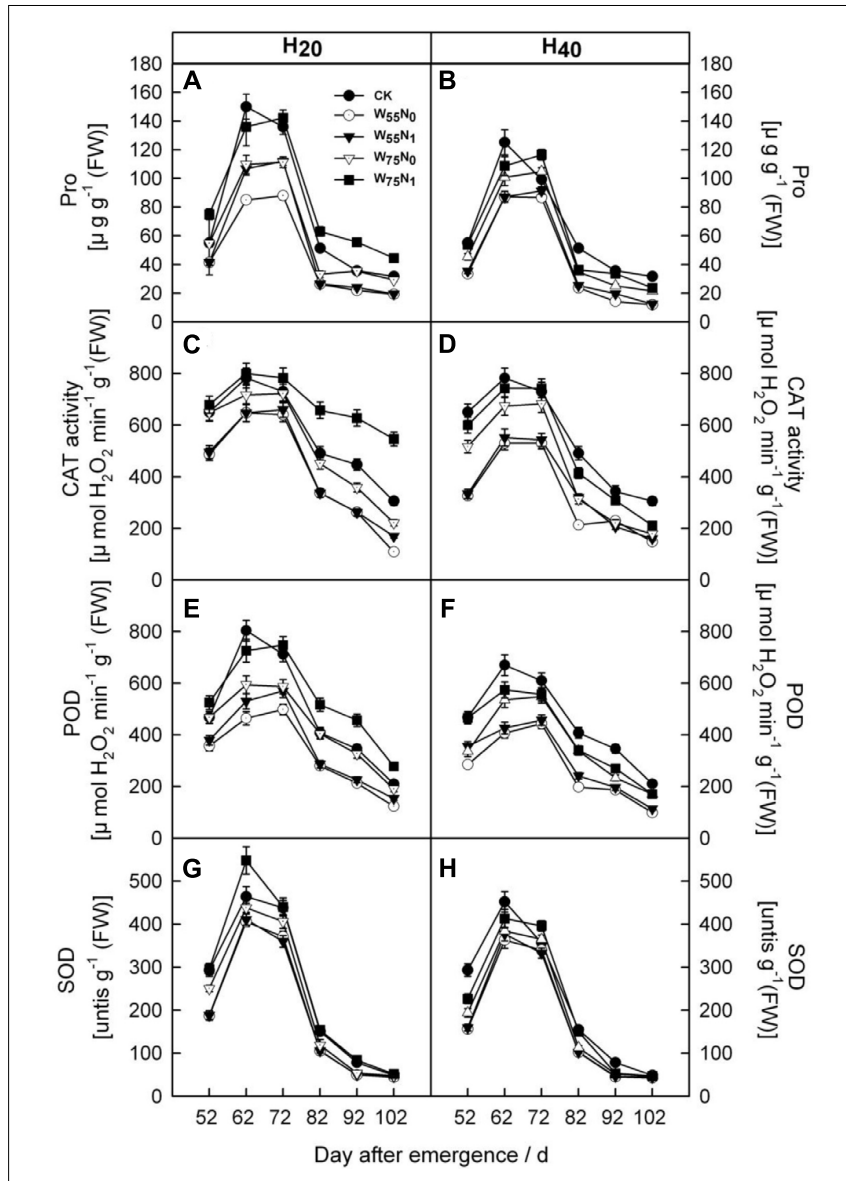

FIGURE 1 | Changes in (A,B) proline [Pro, $\mu \mathrm{g} \mathrm{g}^{-1}$ (FW)], (C,D) catalase [CAT, $\mu \mathrm{mol} \mathrm{H}_{2} \mathrm{O}_{2}$ min $\left.^{-1} \mathrm{~g}^{-1}(\mathrm{FW})\right],(\boldsymbol{E}, \mathbf{F})$ peroxidase [POD, $\mu \mathrm{mol} \mathrm{H}_{2} \mathrm{O}_{2} \mathrm{~min}^{-1} \mathrm{~g}^{-1}$ $(\mathrm{FW})$ ] and $(\mathbf{G}, \mathbf{H})$ superoxide dismutase (SOD, [units $\mathrm{g}^{-1}$ (FW)] in leaf of cotton plant in coupling of irrigation depth and water-nitrogen application rate during 52 to 102 days after emergence. Data are mean $\pm \mathrm{SE}$. $\mathrm{H}_{20}$, watered depth at $20 \mathrm{~cm}$ soil layer; $\mathrm{H}_{40}$, watered depth at $40 \mathrm{~cm}$ soil layer; $W_{75}$, water application rates with $75 \%$ field holding capacity; $W_{55}$, water application rates with $55 \%$ field capacity; $N_{1}$, nitrogen application; $N_{0}$, no nitrogen application; CK, surface irrigation, the irrigated rate of $75 \%$ field capacity and nitrogen application.

grinder for 45 s. Cultural management practices, e.g., weeding, hoeing and pesticide application were implemented according to the cotton demand.

\section{Data Collection and Observations Soil Water Content}

Watermark (Soil Moisture Meter, IRROMETER Inc., NE, United States) was used to assess the change of soil water in the $0-60 \mathrm{~cm}$ soil layer and maintained at $75 \%$ or $55 \%$ soil holding capacity in the $0-60 \mathrm{~cm}$ soil layer during whole growth period. Water supplied defined as:

$$
A=\left(W_{p}-W_{a}\right) \times H
$$

Where $A$ is the volume of water supplied (mm), $W_{p}$ is the field capacity in the $0-60 \mathrm{~cm}$ soil profile for the experiment. $W_{a}$ is the

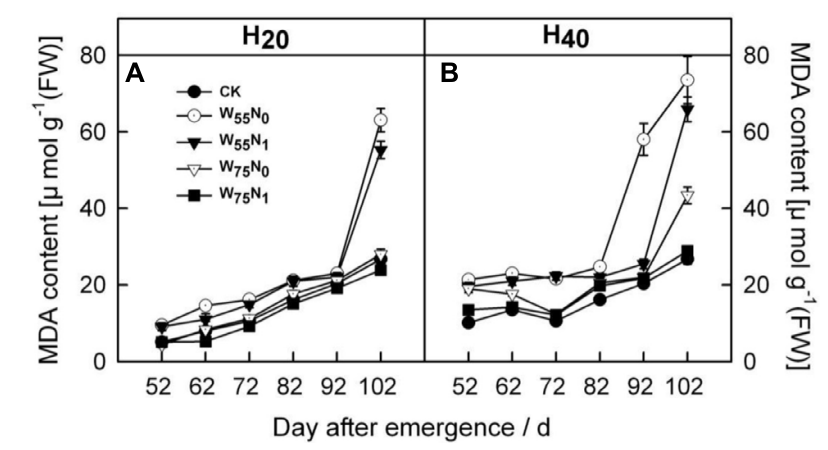

FIGURE 2 | Changes in (A,B) malondialdehyde (MDA, $\mu \mathrm{mol} \mathrm{g}{ }^{-1} \mathrm{FW}$ ) in leaf of cotton plant in coupling of irrigation depth and water-nitrogen application rate during 52 to 102 days after emergence. Data are mean $\pm \mathrm{SE}$. $\mathrm{H}_{20}$, watered depth at $20 \mathrm{~cm}$ soil layer; $\mathrm{H}_{40}$, watered depth at $40 \mathrm{~cm}$ soil layer; $W_{75}$, water application rates with $75 \%$ field capacity; $W_{55}$, water application rates with $55 \%$ field capacity; $N_{1}$, nitrogen application; $N_{0}$, no nitrogen application; $C K$, surface irrigation, the irrigated rate of $75 \%$ field capacity and nitrogen application.

average relative soil moisture content in the $0-60 \mathrm{~cm}$ soil profile that was measured using Watermark, and $H$ is the thickness of the soil layers using drip irrigation system (mm).

\section{Root Growth Measurement}

Root distribution was measured in soil columns at 82 and 102 DAE. Each sector (tube) were carefully dug and cut down into $40 \mathrm{~cm}$ segments at the top of each column. The segments were immersed in water for $1 \mathrm{~h}$ and the roots from each soil layer were rinsed with tap water. Plant debris, weeds, and dead roots were sorted concurrently from 'live' roots by hand according to (Gwenzi et al., 2011). Live roots from each sector were evenly spread in a plastic tray containing deionized water and scanned using a flatbed scanner (300 dpi). Root images were analyzed using WinRhizo image analysis software (Regent Instruments, Quebec, Canada). The software was configured to measure RLD and RSD. After scanning, the roots were oven-dried at $80^{\circ} \mathrm{C}$ for $48 \mathrm{~h}$ and root dry mass was weighed to calculate RMD; the RLD, the RSD and the RMD were expressed as $\mathrm{cm}, \mathrm{cm}^{2}$, and $\mathrm{mg}$ per unit volume $\left(\mathrm{cm}^{3}\right)$ of soil, respectively.

\section{Proline Content and Nitrate Reductase Activity}

Free proline content of cotton leaves was assayed according to the method (Bates et al., 1973). The samples were homogenized in $5 \mathrm{~mL}$ of $3 \%$ sulfosalicylic acid and centrifuged at $6000 \mathrm{rpm}$ for $10 \mathrm{~min}$. Supernatant was heated with $2 \mathrm{~mL}$ of ninhydrin and glacial acetic acid at $100^{\circ} \mathrm{C}$ for $1 \mathrm{~h}$, respectively. The reaction was further extracted with $4 \mathrm{~mL}$ of toluene by vigorously vortexed for $30 \mathrm{~s}$. The absorption of chromophore was determined at $520 \mathrm{~nm}$ (Tecan-infinite M200, Switzerland). Nitrate reductase (NR) activity of root and shoot samples were determined by an in vivo assay described previously (Radin, 1974).

\section{Lipid Peroxidation}

Lipid peroxidation in cotton roots (including the roots in each soil layer) and leaves were determined as MDA content using 


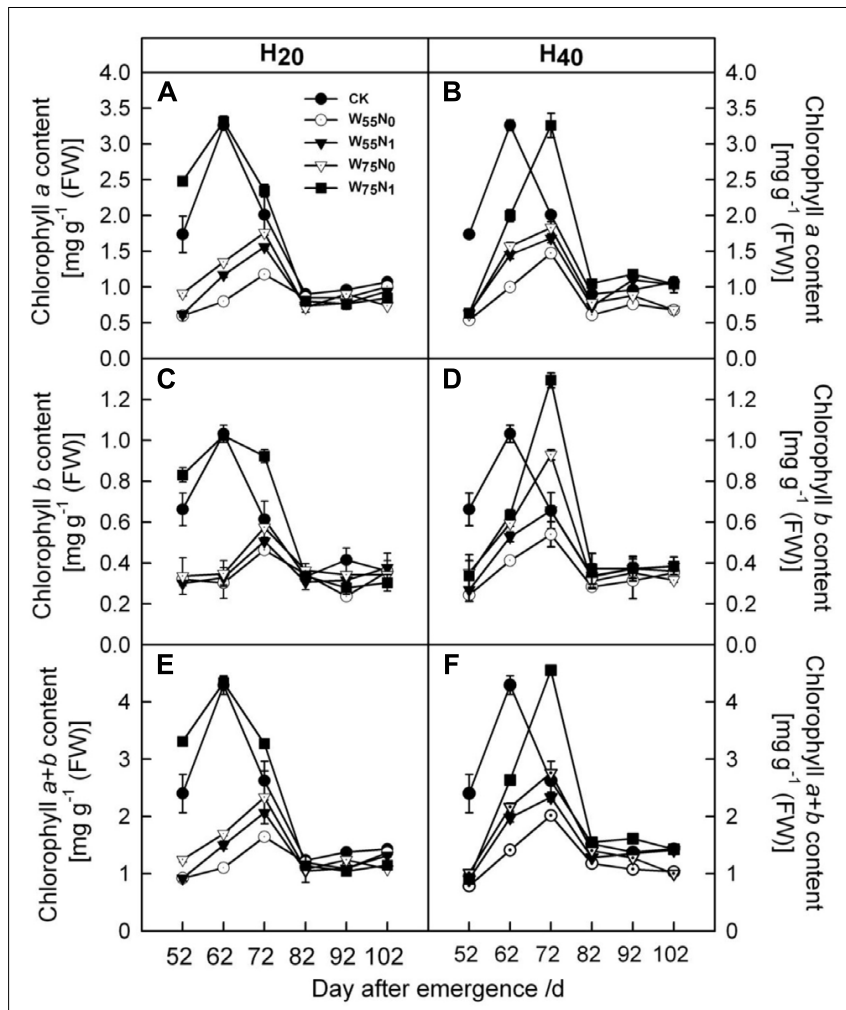

FIGURE 3 | Changes in (A,B) chlorophyll a $\left[\mathrm{mg} \mathrm{g}^{-1}(\right.$ FW)], (C,D) chlorophyll b $\left[\mathrm{mg} \mathrm{g}^{-1}(\mathrm{FW})\right]$ and $(\mathbf{E}, \mathbf{F})$ chlorophyll $a+b\left[\mathrm{mg} \mathrm{g}^{-1}(\mathrm{FW})\right]$ in leaf of cotton plant in coupling of irrigation depth and water-nitrogen application rate during 52 to 102 days after emergence. Data are mean $\pm \mathrm{SE}$. $\mathrm{H}_{20}$, watered depth at $20 \mathrm{~cm}$ soil layer; $\mathrm{H}_{40}$, watered depth at $40 \mathrm{~cm}$ soil layer; $W_{75}$, water application rates with $75 \%$ field capacity; $W_{55}$, water application rates with $55 \%$ field capacity; $N_{1}$, nitrogen application; $N_{0}$, no nitrogen application; $C K$, surface irrigation, the irrigated rate of $75 \%$ field capacity and nitrogen application.

the thiobarbituric acid method (Bailly et al., 1996). A $1.0 \mathrm{ml}$ aliquot of supernatant of tissue extract (root or leaf) was mixed with $4 \mathrm{ml}$ of $20 \%(\mathrm{v} / \mathrm{v})$ trichloroacetic acid containing $0.5 \%$ (v/v) thiobarbituric acid. The mixture was heated at $100^{\circ} \mathrm{C}$ for $30 \mathrm{~min}$, cooled down and centrifuged at 10,000 rpm for $10 \mathrm{~min}$. The absorbance of the supernatant was assayed at 532 and $600 \mathrm{~nm}$.

\section{Antioxidant Enzymes (SOD, POD, and CAT) Activities in Root and Leaf}

The activities of enzymatic antioxidants viz., SOD, POD, and CAT in root and leaf were assessed according to (Zheng et al., 2016) standard procedure. The SOD activity was the amount of extract that gives $50 \%$ inhibition in nitrotetrazolium blue chloride (NBT) photoreduction as detected at $560 \mathrm{~nm}$ (Tecan-infinite M200, Switzerland). The POD activity was based on the determination of guaiacol oxidation at $470 \mathrm{~nm}$ by $\mathrm{H}_{2} \mathrm{O}_{2}$ and was presented as $\mu \mathrm{mol} \mathrm{H}_{2} \mathrm{O}_{2} \mathrm{~g}^{-1}$ (FW). The change in absorbance at $470 \mathrm{~nm}$ was recorded every min by spectrophotometer. One unit of POD activity is the amount

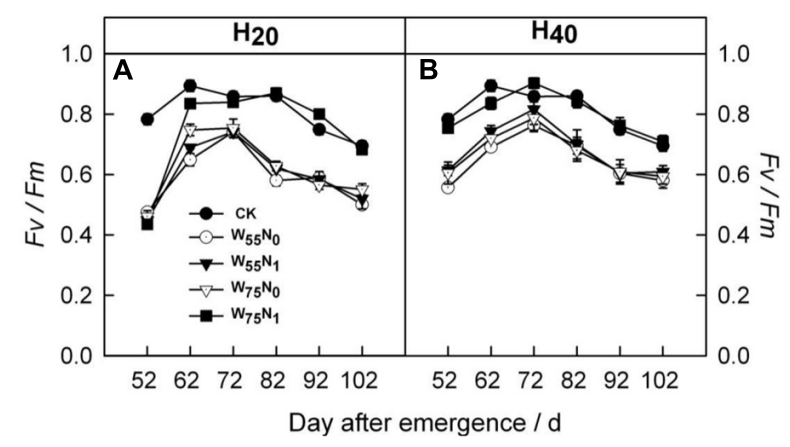

FIGURE 4 | Changes in (A,B) potential quantum yield of photosystem II $\left(F_{v} / F_{m}\right)$ of cotton plant in coupling of irrigation depth and water-nitrogen application rate during 52 to 102 days after emergence. Data are mean $\pm \mathrm{SE}$. $\mathrm{H}_{20}$, watered depth at $20 \mathrm{~cm}$ soil layer; $\mathrm{H}_{40}$, watered depth at $40 \mathrm{~cm}$ soil layer; $W_{75}$, water application rates with $75 \%$ field capacity; $W_{55}$, water application rates with $55 \%$ field capacity; $N_{1}$, nitrogen application; $N_{0}$, no nitrogen application; CK, surface irrigation, the irrigated rate of $75 \%$ field capacity and nitrogen application.

of enzyme that causes the decomposition of $1 \mu \mathrm{g}$ substrate at $470 \mathrm{~nm}$ for $1 \mathrm{~min}$ in $1 \mathrm{~g}$ fresh sample at $37^{\circ} \mathrm{C}$. The CAT activity was measured using $0.5 \mathrm{~g}$ fresh leaf sample according to Cakmak and Marschner (1992). The CAT activity was defined as the amount of enzyme that causes the decomposition of $1 \mu \mathrm{mol} \mathrm{H}_{2} \mathrm{O}_{2}$ at $405 \mathrm{~nm}$ per min in $1 \mathrm{~g}$ fresh sample at $37^{\circ} \mathrm{C}$.

\section{Chlorophyll, Chlorophyll Fluorescence and Leaf Gas Exchange Parameters}

All the treatments at each sampled day (for example, 36 samples with four replicates at $52 \mathrm{DAE}$ ) were hand grounded and measured using a spectrophotometer within $90 \mathrm{~min}$ to avoid the acetone volatilization. Chlorophyll (Chl) $a$ and $b$ in each sample were extracted from $0.1 \mathrm{~g}$ ground fresh leaf mixed with $10 \mathrm{ml}$ of $80 \%$ acetone and was measured at 663 and $645 \mathrm{~nm}$ according to the method described by Arnon (1949):

$$
\begin{aligned}
& C_{(\text {Chl } a)}=12.71 D_{663}-2.59 D_{645} \\
& C_{(\text {Chl b })}=22.88 D_{645}-4.67 D_{663}
\end{aligned}
$$

Where $\left.C_{(\mathrm{Chl}} a\right)$ or $\left.C_{(\mathrm{Chl}} b\right)$ is the content of the Chl $a$ or $b$; $D_{663}$ or $D_{645}$ is the absorbance at 663 or $645 \mathrm{~nm}$ using a spectrophotometer (Tecan-infinite M200, Switzerland).

Chlorophyll fluorescence was assessed during diurnal time using a portable saturation pulse fluorometer PAM-2100 equipped with a 2030-B leaf clip holder (Walz, Effeltrich, Germany). Maximal $\left(F_{m}\right)$ and ground $\left(F_{o}\right)$ fluorescence yields of dark-adapted leaves were measured between 05:30 and 06:30. The $F_{o}$ was obtained with a measuring light of $0.5 \mu \mathrm{mol} \mathrm{m}{ }^{-2}$ $\mathrm{s}^{-1}$ at a frequency of $0.6 \mathrm{kHz}$, while the $F_{m}$ was measured with a $0.8 \mathrm{~s}$ saturating pulse at $>8,000 \mu \mathrm{mol} \mathrm{m} \mathrm{m}^{-2} \mathrm{~s}^{-1}$. Potential quantum yield of PSII $\left(F_{v} / F_{m}\right)$ was calculated where $F_{v}$ is the maximum variable fluorescence $\left(F_{v}=F_{m}-F_{o}\right)$. During the 


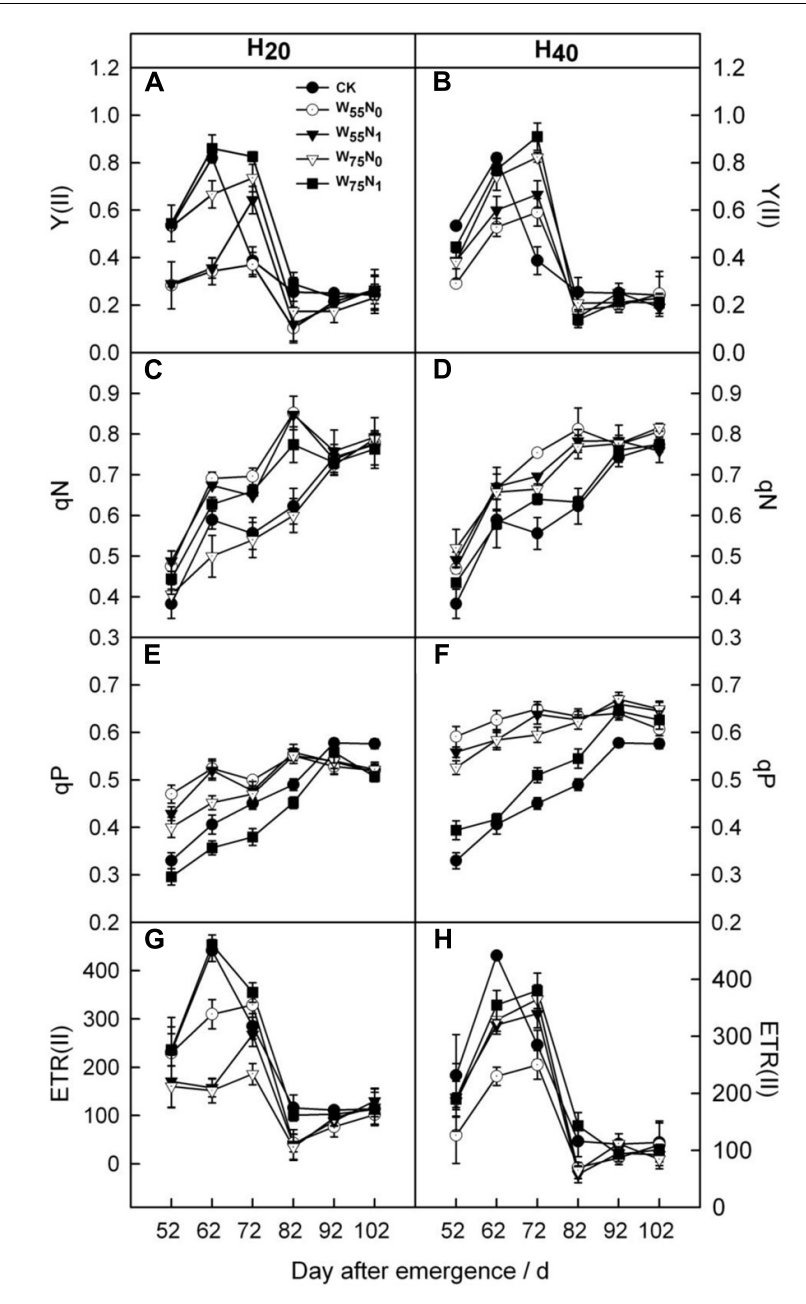

FIGURE 5 | Changes in (A,B) PSII quantum yield in the light $[Y(I I)]$, (C,D) non-photochemical quenching coefficient (qN), (E,F) photochemical quenching coefficient $(\mathrm{QP})$ and $(\mathbf{G}, \mathbf{H})$ the electron transport rate of $\mathrm{PSI}$ [ETR(II)] of cotton plant in coupling of irrigation depth and water-nitrogen application rate during 52 to 102 days after emergence. Data are mean \pm SE. $\mathrm{H}_{20}$, watered depth at $20 \mathrm{~cm}$ soil layer; $\mathrm{H}_{40}$, watered depth at $40 \mathrm{~cm}$ soil layer; $W_{75}$, water application rates with $75 \%$ field capacity; $W_{55}$, water application rates with $55 \%$ field capacity; $\mathrm{N}_{1}$, nitrogen application; $\mathrm{N}_{0}$, no nitrogen application; CK, surface irrigation, the irrigated rate of $75 \%$ field capacity and application nitrogen.

diurnal time, $F_{\mathrm{s}}$ (fluorescence of the light-adapted leaf) and $F_{\mathrm{m}}^{\prime}$ (the maximum light-adapted fluorescence) were measured. The $F_{\mathrm{S}}$ was obtained at a frequency of $20 \mathrm{kHz} ; F_{\mathrm{m}}^{\prime}$ was measured with a $0.8 \mathrm{~s}$ saturating pulse at $>8,000 \mu \mathrm{mol} \mathrm{m}^{-2} \mathrm{~s}^{-1}$. The $\mathrm{Y}$ (II) was calculated as $\left(F_{\mathrm{m}}^{\prime}-F_{\mathrm{s}}\right) / F_{\mathrm{m}}^{\prime}$ (Genty et al., 1989). qP was calculated, i.e., $\left(F_{\mathrm{m}}^{\prime}-F_{\mathrm{s}}\right) /\left(F_{\mathrm{m}}^{\prime}-F_{\mathrm{o}}^{\prime}\right)$ according to (Krause and Weis, 1991). Minimal fluorescence under light condition $\left(F_{\mathrm{o}}^{\prime}\right)$ was assessed by using the equation $F_{\mathrm{o}}^{\prime}=F_{o} /\left(F_{v} / F_{m}+F_{o} / F_{\mathrm{m}}^{\prime}\right)$ as suggested by Oxborough and Baker (1997). qN was determined, i.e., $\left(F_{m}-F_{\mathrm{m}}^{\prime}\right) / F_{\mathrm{m}}^{\prime}$, where $F_{m}$ is the value of the predawn measurements using the (Bilger and Björkman, 1990) method. The ETR was assessed using a leaf absorptance of 0.85 and that

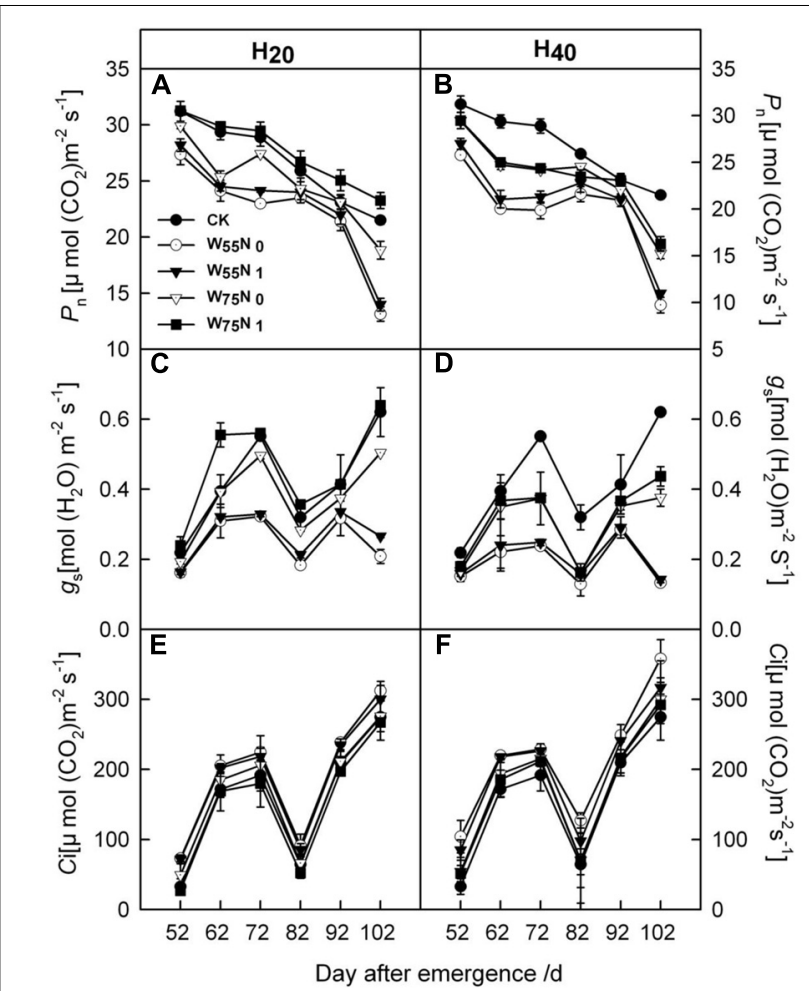

FIGURE 6 | Changes in $(\mathbf{A}, \mathbf{B})$ the net photosynthetic rate $\left[P_{\mathrm{n}}, \mu \mathrm{mol}\left(\mathrm{CO}_{2}\right)\right.$ $\left.\mathrm{m}^{-2} \mathrm{~s}^{-1}\right]$, (C,D) stomatal conductance $\left[\mathrm{g}_{\mathrm{s}}, \mathrm{mol}\left(\mathrm{H}_{2} \mathrm{O}\right) \mathrm{m}^{-2} \mathrm{~s}^{-1}\right]$ and (E,F) intercellular $\mathrm{CO}_{2}$ concentration $\left[C_{i}, \mu \mathrm{mol}\left(\mathrm{CO}_{2}\right) \mathrm{m}^{-2} \mathrm{~s}^{-1}\right]$ in leaf of cotton plant in coupling of irrigation depth and water-nitrogen application rate during 52 to 102 days after emergence. Data are mean $\pm \mathrm{SE}$. $\mathrm{H}_{20}$, watered depth at $20 \mathrm{~cm}$ soil layer; $\mathrm{H}_{40}$, watered depth at $40 \mathrm{~cm}$ soil layer; $W_{75}$, water application rates with $75 \%$ field capacity; $W_{55}$, water application rates with $55 \%$ field capacity; $N_{1}$, nitrogen application; $N_{0}$, no nitrogen application; CK, surface irrigation, the irrigated rate of $75 \%$ field capacity and application nitrogen.

half of the absorbed light was partitioned to each photosystem: $\mathrm{ETR}(\mathrm{II})=\mathrm{Y}(\mathrm{II}) \times \mathrm{PPFD} \times 0.85 \times 0.5$, in the equation, PPFD incident on the same position of the leaf surface and the leaf was kept under natural conditions, 0.5 indicated that two photons are used for exciting one electron by assuming an equal distribution of excitation between photosystems II and I (Krall and Edwards, 1992), 0.85 is considered the most common leaf absorbance coefficient for $\mathrm{C}_{3}$ plants (Björkman and Demmig, 1987) under different environmental conditions and leaf age (Schultz, 1996).

The $P_{\mathrm{n}}, g_{\mathrm{s}}$ and $C_{\mathrm{i}}$ were measured between 10:00 and 12:00 h using a photosynthesis system (Li-6400, Li-COR Inc., Lincoln, NE, United States). The light intensity was configured at $1,800 \mu \mathrm{mol} \mathrm{m}^{-2} \mathrm{~s}^{-1}$ and other parameters varied over a narrow range, $\left[25-32^{\circ} \mathrm{C}, 330-350 \mu \mathrm{mol}\left(\mathrm{CO}_{2}\right) \mathrm{mol}^{-1}\right]$ for all treatments.

\section{Dry Mass Production}

Twelve plants (three PVC tubes) were selected from each treatment and cut down at the cotyledon position after photosynthesis and chlorophyll fluorescence were measured. Plants were carefully dissected into leaves, stems, buds, flowers 


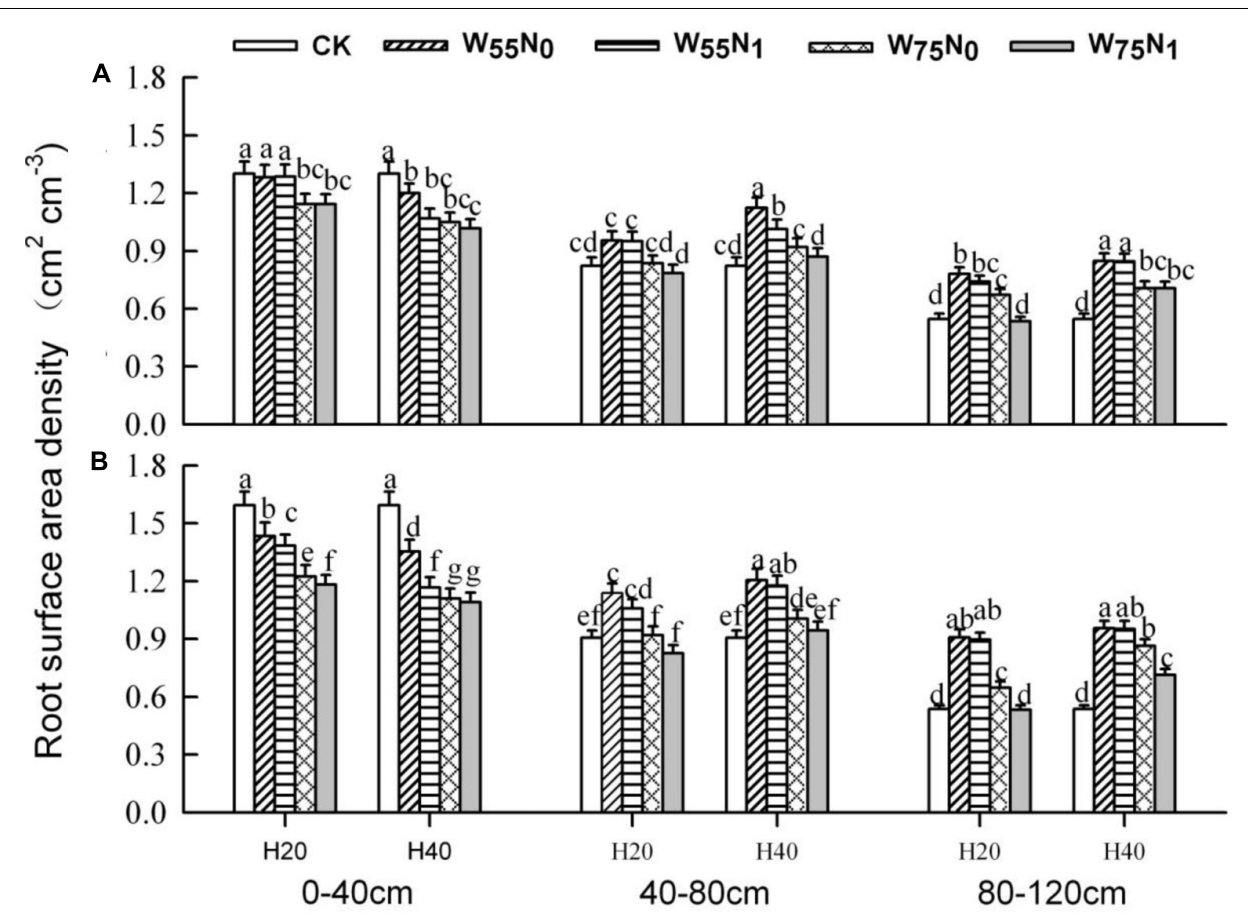

FIGURE 7 | Changes in root surface area density (RSD, $\mathrm{cm}^{2} \mathrm{~cm}^{-3}$ ) of cotton plant in coupling of irrigation depth and water-nitrogen application rate at 82 days (A) and 102 days (B) after emergence. Data are mean \pm SE, different letters indicate a significant difference $(p<0.05)$ among the treatments in one soil layer at 82 days or 102 days. $\mathrm{H}_{20}$, watered depth at $20 \mathrm{~cm}$ soil layer; $\mathrm{H}_{40}$, watered depth at $40 \mathrm{~cm}$ soil layer; $W_{75}$, water application rates with $75 \%$ field holding capacity; $W_{55}$, water application rates with $55 \%$ field capacity; $N_{1}$, nitrogen application; $N_{0}$, no nitrogen application; CK, surface irrigation, the irrigated rate of $75 \%$ field capacity and nitrogen application.

and bolls. Samples were dried at $80^{\circ} \mathrm{C}$ for $48 \mathrm{~h}$ and weighed for determination of dry mass.

\section{Statistical Analysis}

Analysis of variance (ANOVA) and correlation analysis were performed using SPSS 16.0 software. Differences between treatments were considered significant at $P<0.01$ according to least significant difference (LSD) tests. The figures were plotted using SigmaPlot 10.0 software.

\section{RESULTS}

\section{Biomass Accumulation and Allocation}

Cotton plant dry matter accumulation was significantly influenced by irrigation modes and $\mathrm{N}$ rates. $\mathrm{H}_{20}$ compared with $\mathrm{H}_{40}$ produced $26.5,33.7$, and $33.4 \%$ more total dry mass reproductive organ and leaf biomass accumulation, respectively. In contrast, the root dry matter accumulation was decreased by $15 \%$ for $\mathrm{H}_{20}$ (Table 1) compared to $\mathrm{H}_{40}$. Under $\mathrm{H}_{20}$ condition, the total dry matter in $\mathrm{W}_{75} \mathrm{~N}_{1}$ increased by $29.0,47.1,78.1$, and $82 \%$ than $C K, W_{75} \mathrm{~N}_{0}, \mathrm{~W}_{55} \mathrm{~N}_{1}$, and $\mathrm{W}_{55} \mathrm{~N}_{0}$, respectively, reproductive structures dry matter in $\mathrm{W}_{75} \mathrm{~N}_{1}$ were $46.6,59.0,91.2$, and $101.2 \%$ more, while the root biomass in $\mathrm{W}_{75} \mathrm{~N}_{1}$ decreased by $2.5,20.2,41.1$, and $52.7 \%$ compared with $\mathrm{CK}, \mathrm{W}_{75} \mathrm{~N}_{0}, \mathrm{~W}_{55} \mathrm{~N}_{1}$, and $\mathrm{W}_{55} \mathrm{~N}_{0}$, respectively.

\section{The Enzymatic Activity and Pigment Content in Leaf}

With the plant development cotton leaf Pro (Figures 1A,B), CAT (Figures 1C,D), POD (Figures 1E,F), and SOD (Figures 1G,H) firstly rose and then declined later in the season. Cotton leaf Pro, CAT, POD, and SOD were increased by 6.2-19.9, 20.7-26.8, 17.8-240.4, 40-344.4, 35.0-110.1, 58.9-186.8, 2.0-5.5, and 4.0-44.0 in $\mathrm{H}_{20}$ compared with $\mathrm{CK}$ and $\mathrm{H}_{40}$. The Pro, CAT, $\mathrm{POD}$, and SOD declined in the following order, $\mathrm{W}_{75} \mathrm{~N}_{1}, \mathrm{~W}_{55} \mathrm{~N}_{1}$, $\mathrm{W}_{75} \mathrm{~N}_{0}$, and $\mathrm{W}_{55} \mathrm{~N}_{0}$ under both $\mathrm{H}_{20}$ and $\mathrm{H}_{40}$. Leaf MDA content was increased as the plant grew, the MDA accumulation in $\mathrm{H}_{20}$ was 1.1-2.7 and 2.6-8.4 lower, respectively, compared with CK and $\mathrm{H}_{20}$ during whole growth season (Figure 2).

As the plant grew, cotton leaf $\mathrm{Chl} a$ and $b$ increased but decreased later in the season (Figure 3 ). The Chl $a$ and $b$ content was $0.05-0.74$ and 1.31-1.84 more in $\mathrm{H}_{20}$ than $\mathrm{H}_{40}$ before 82 DAE. $\mathrm{H}_{20}$ combined with $\mathrm{W}_{75} \mathrm{~N}_{1}$ resulted in higher $\mathrm{Chl} a$ and $b$ content compared with other combinations.

\section{Chlorophyll Fluorescence, Photosystem II and Leaf Gas Exchange Parameters}

Most of the chlorophyll fluorescence, PSII and gas exchange parameters of cotton leaves were significantly influenced by irrigation methods and $\mathrm{N}$ levels.

The $\mathrm{H}_{20}$ treatment exhibited 6.8 and $3.2 \%$ increment in $F_{v} / F_{m}$ compared with $\mathrm{CK}$ and $\mathrm{H}_{40}$ after $72 \mathrm{DAE}$ (Figure 4). 


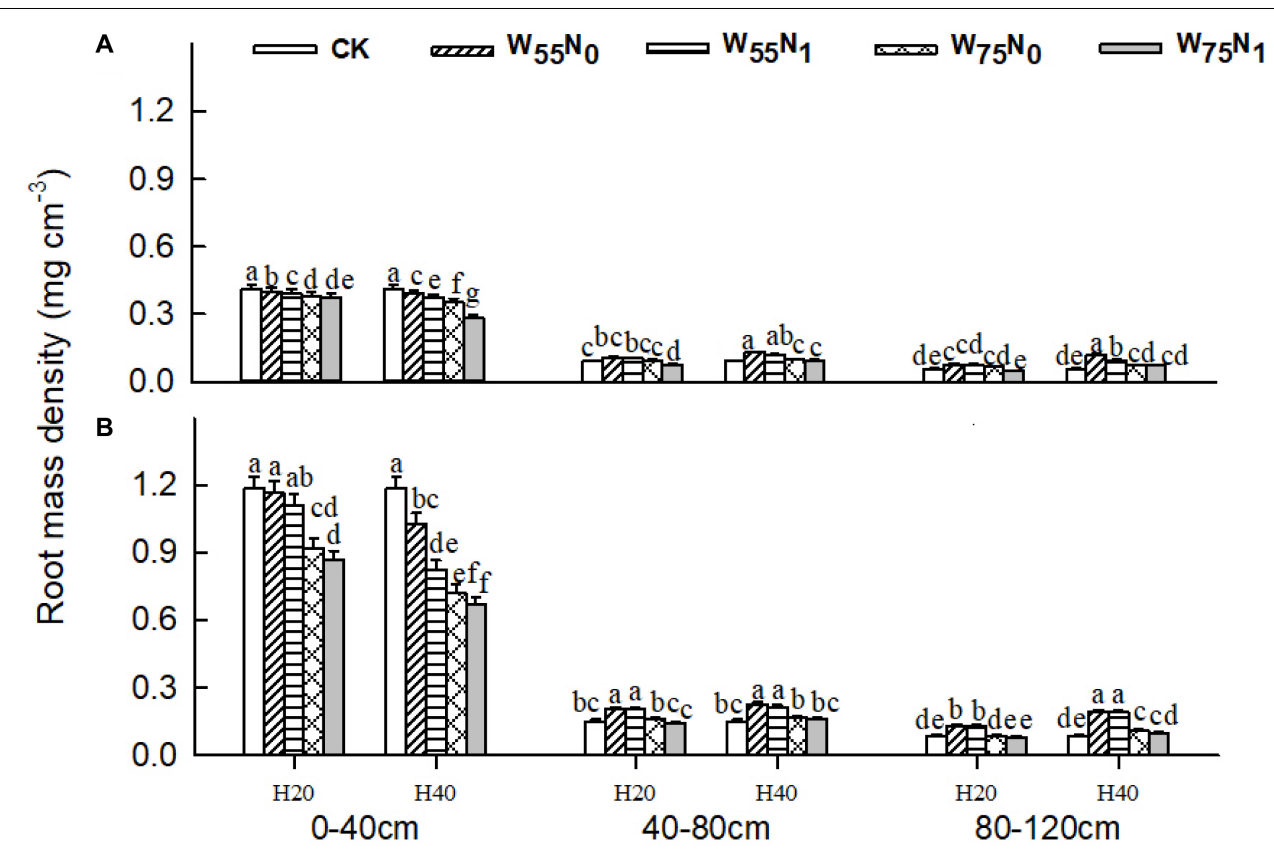

FIGURE 8 | Changes in root mass density (RMD, $\mathrm{mg} \mathrm{cm}^{-3}$ ) of cotton plant in coupling of irrigation depth and water-nitrogen application rate at 82 days (A) and 102 days (B) after emergence. Data are mean \pm SE, different letters indicate a significant difference $(p<0.05)$ among the treatments in one soil layer at 82 days or 102 days. $\mathrm{H}_{20}$, watered depth at $20 \mathrm{~cm}$ soil layer; $\mathrm{H}_{40}$, watered depth at $40 \mathrm{~cm}$ soil layer; $W_{75}$, water application rates with $75 \%$ field capacity; $W_{55}$, water application rates with $55 \%$ field holding capacity; $\mathrm{N}_{1}$, nitrogen application; $\mathrm{N}_{0}$, no nitrogen application; CK, surface irrigation, the irrigated rate of $75 \%$ field capacity and nitrogen application.

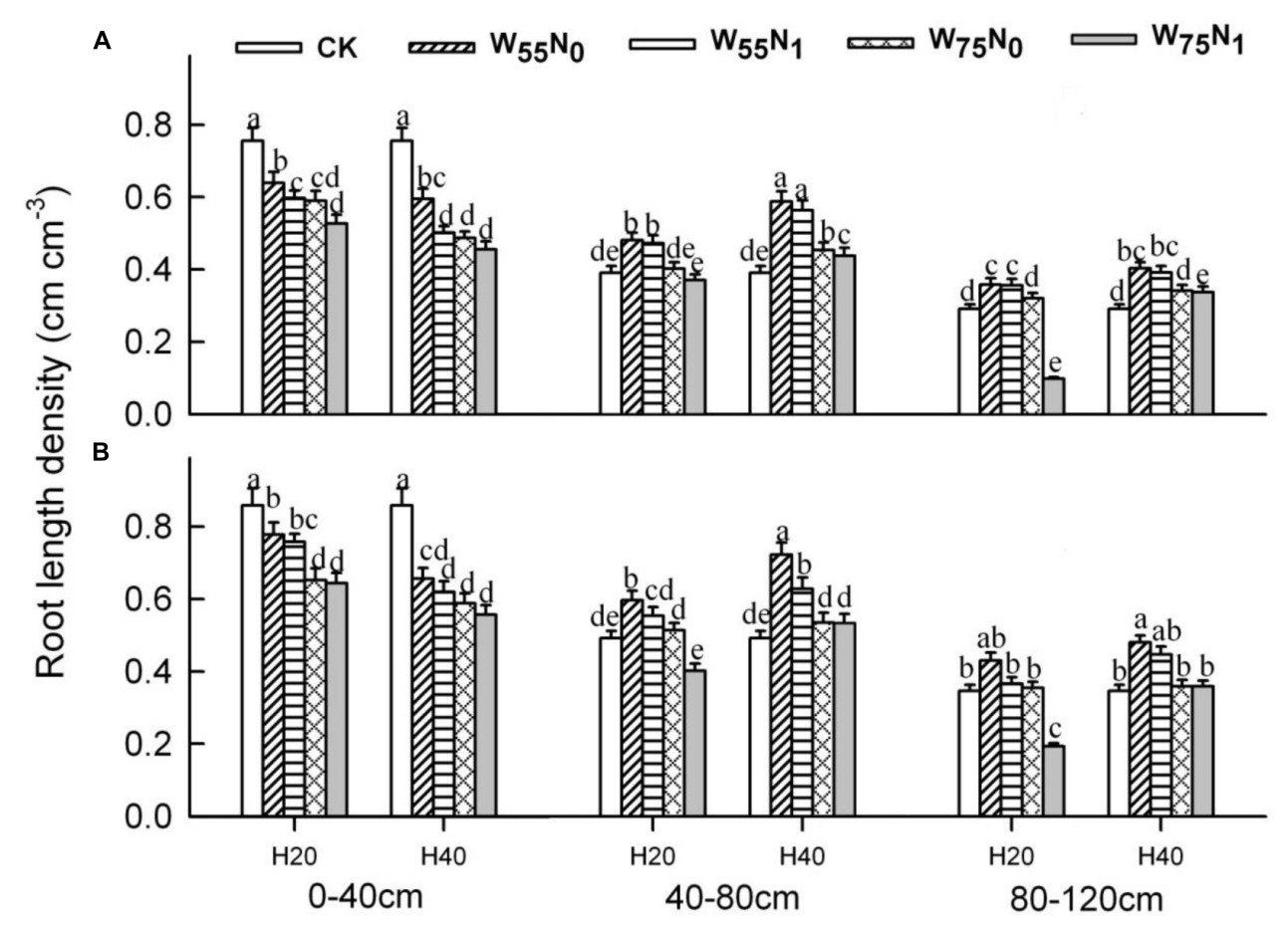

FIGURE 9 | Changes in root length density (RLD, $\mathrm{cm} \mathrm{cm}^{-3}$ ) of cotton plant in coupling of irrigation depth and water-nitrogen application rate at 82 days (A) and 102 days (B) after emergence. Data are mean \pm SE, different letters indicate a significant difference $(p<0.05)$ among the treatments in one soil layer at 82 days or 102 days. $\mathrm{H}_{20}$, watered depth at $20 \mathrm{~cm}$ soil layer; $\mathrm{H}_{40}$, watered depth at $40 \mathrm{~cm}$ soil layer; $W_{75}$, water application rates with $75 \%$ field capacity; $W_{55}$, water application rates with $55 \%$ field holding; $N_{1}$, nitrogen application; $N_{0}$, no nitrogen application; CK, surface irrigation, the irrigated rate of $75 \%$ field holding capacity and nitrogen application. 


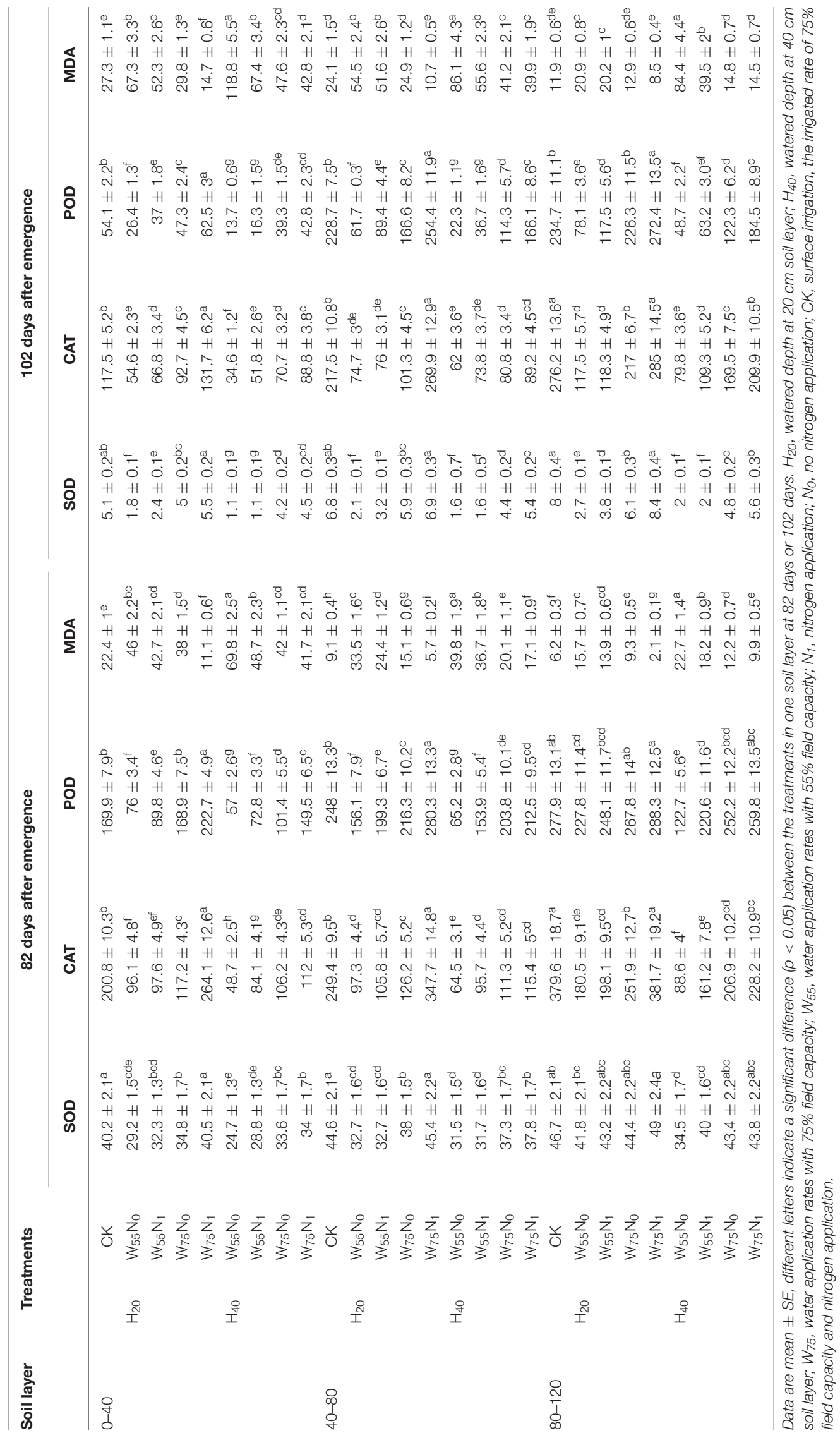



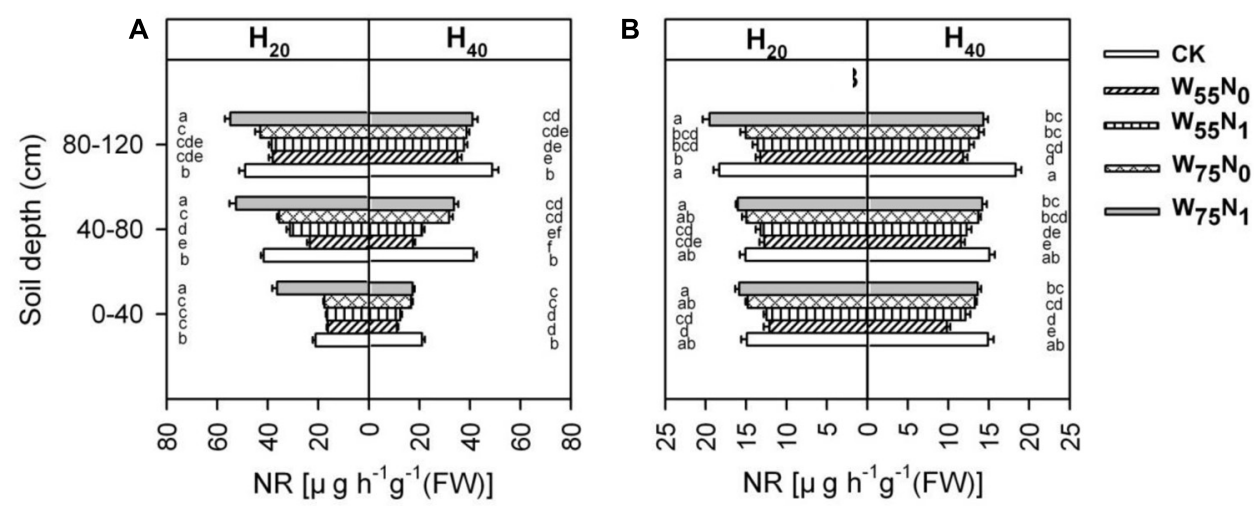

FIGURE 10 | Changes in nitrate reductase [NR, $\left.\mathrm{ug} \mathrm{h}^{-1} \mathrm{~g}^{-1}(\mathrm{FW})\right]$ in roots of cotton plant in coupling of irrigation depth and water-nitrogen application rate at 82 days $\mathbf{( A )}$ and 102 days $\mathbf{( B )}$ after emergence. Data are mean $\pm \mathrm{SE}$, different letters indicate a significant difference $(p<0.05)$ among the treatments in one soil layer at 82 days or 102 days. $\mathrm{H}_{20}$, watered depth at $20 \mathrm{~cm}$ soil layer; $\mathrm{H}_{40}$, watered depth at $40 \mathrm{~cm}$ soil layer; $W_{75}$, water application rates with $75 \%$ field capacity; $W_{55}$, water application rates with $55 \%$ field capacity; $N_{1}$, nitrogen application; $N_{0}$, no nitrogen application; CK, surface irrigation, the irrigated rate of $75 \%$ field capacity and nitrogen application.

The $\mathrm{H}_{20} \mathrm{~W}_{75} \mathrm{~N}_{1}$ combination had higher $F_{v} / F_{m}$ followed by other counterparts in $\mathrm{H}_{20}$ and $\mathrm{H}_{40}$ conditions after 72 DAE.

The Y(II) and ETR(II) were increased by $0.011-0.44$ and 0.09-0.15, and 4.6-70 and 46.3-99.0 in $\mathrm{H}_{20}$ compared with CK and $\mathrm{H}_{40}$ before $82 \mathrm{DAE}$ (Figure 5). In contrast, $\mathrm{qN}$ and $\mathrm{qP}$ was decreased under $\mathrm{H}_{20}$ conditions during whole growth season. In addition, $\mathrm{H}_{20} \mathrm{~W}_{75} \mathrm{~N}_{1}$ resulted in highest $\mathrm{Y}$ (II) and $\mathrm{ETR}$ (II) compared with other combinations before $82 \mathrm{DAE}$.

Most of the cotton leaf gas exchange parameters, i.e., $P_{\mathrm{n}}$, $g_{s}$ were increased by $0.06-1.93$ and $1.8-7.0$, and $0.01-1.6$ and 0.06-0.2 in the $\mathrm{H}_{20}$ compared with $\mathrm{CK}$ and $\mathrm{H}_{40}$ during whole growth season (Figure 6). In contrast, $C_{\mathrm{i}}$ was higher in $\mathrm{H}_{40}$ treatment than in $\mathrm{H}_{20}$ and $\mathrm{CK}$ during whole growth season. $\mathrm{H}_{20} \mathrm{~W}_{75} \mathrm{~N}_{1}$ exhibited highest values for $P_{\mathrm{n}}$ and $g_{\mathrm{s}}$ compared with other treatments during the whole growth season.

\section{Root Morphological Features}

The plants grown in the $0-40 \mathrm{~cm}$ soil layer with $\mathrm{H}_{20}$ was $11.0-13.0 \%$ and $15.6-16.9 \%$ and $11.8-25.1 \%$ higher for RSD,
RLD, and RMD, respectively, at 82 and 102 DAE, compared with $\mathrm{H}_{40}$ (Figures 7-9); in the 40-120 cm soil layer, RSD, RLD, and RMD were $12.8-12.5 \%, 19.2-23.0 \%$ and $1.9-19.6 \%$ lower for $\mathrm{H}_{20}$ compared with $\mathrm{H}_{40}$. Under $\mathrm{H}_{20}$ or $\mathrm{H}_{40}$ conditions, $\mathrm{RSD}$ and RLD decreased in the order $\mathrm{W}_{55} \mathrm{~N}_{0}, \mathrm{~W}_{75} \mathrm{~N}_{0}, \mathrm{~W}_{55} \mathrm{~N}_{1}$, and $\mathrm{W}_{75} \mathrm{~N}_{1}$.

\section{Root Physiological Features}

In the $0-80 \mathrm{~cm}$ soil layer, the CAT, POD, and SOD activity were significantly higher in $\mathrm{H}_{20}$ compared with $\mathrm{H}_{40}$ (Table 2), although the MDA showed a reverse trend. Cotton roots proline (Pro) content, CAT, POD, and SOD activity declined under $\mathrm{H}_{20}$ or $\mathrm{H}_{40}$ condition in the following order, $\mathrm{W}_{75} \mathrm{~N}_{1}, C K, \mathrm{~W}_{55} \mathrm{~N}_{1}$, $\mathrm{W}_{75} \mathrm{~N}_{0}$, and $\mathrm{W}_{55} \mathrm{~N}_{0}$, while MDA rose in the $0-80 \mathrm{~cm}$ soil layer at 82 and 102 DAE.

Root NR was significantly influenced by the study factors (Figure 10). NR activity of root was significantly higher for $\mathrm{H}_{20}$ compared with $\mathrm{H}_{40}$ in whole soil layer at 82 and 102 DAE. Under $\mathrm{H}_{20}$ conditions, the NR activity was $21.6,37.9,53.8$, and

TABLE 3 | Relationship among nitrate reductase $\left[\mathrm{NR}, \mu \mathrm{g} \mathrm{h}^{-1} \mathrm{~g}^{-1}\right.$ (FW)] and malondialdehyde [MDA, $\mu \mathrm{mol} \mathrm{g}^{-1}$ (FW)] in root, root surface area density (RSD, $\mathrm{cm}^{2} \mathrm{~cm}^{-3}$ ), root mass density (RMD, $\mathrm{mg} \mathrm{cm}{ }^{-3}$ ), root length density (RLD, $\mathrm{cm} \mathrm{cm}^{-3}$ ) and potential quantum yield of photosystem II ( $\left(F_{v} / F_{m}\right)$, PSIl quantum yield in the light $[Y(I I)]$, the electron transport rate of PSII, chlorophyll a $\left[\mathrm{mg} \mathrm{g}^{-1}(\mathrm{FW})\right]$ and stomatal conductance $\left[\mathrm{g}_{\mathrm{s}}, \mathrm{mol}\left(\mathrm{H}_{2} \mathrm{O}\right) \mathrm{m}^{-2} \mathrm{~s}^{-1}\right]$ in leaf of cotton plant at 82 and 102 days after emergence in coupling of irrigation depth and water-nitrogen application rate.

\begin{tabular}{|c|c|c|c|c|c|c|c|c|c|}
\hline & NR & MDA & RSD & RMD & RLD & $\mathrm{Fv} / \mathrm{Fm}$ & PSII & Chlorophyll & $g_{\mathrm{s}}$ \\
\hline MDA & - & 1.000 & -0.027 & -0.006 & -0.188 & $-0.552^{* *}$ & $-0.496^{* *}$ & -0.177 & $-0.856^{* *}$ \\
\hline $\mathrm{RMD}$ & - & - & - & 1.000 & $0.794^{* *}$ & -0.254 & 0.327 & -0.283 & 0.357 \\
\hline RLD & - & - & - & - & 1.000 & -0.055 & 0.169 & 0.043 & $0.413^{*}$ \\
\hline$F_{v} / F_{m}$ & - & - & - & - & - & 1.000 & $0.651^{* *}$ & $0.568^{* *}$ & $0.472^{*}$ \\
\hline Chlorophyll & - & - & - & - & - & - & - & 1.000 & 0.266 \\
\hline$g_{\mathrm{s}}$ & - & - & - & - & - & - & - & - & 1.000 \\
\hline
\end{tabular}

** and *, respectively, indicated highly significant differences $(p<0.01)$ and significant differences $(p<0.05)$. 
$66.5 \%$ higher for $\mathrm{W}_{75} \mathrm{~N}_{1}$ compared with $\mathrm{CK}, \mathrm{W}_{75} \mathrm{~N}_{0}, \mathrm{~W}_{55} \mathrm{~N}_{1}$, and $\mathrm{W}_{55} \mathrm{~N}_{0}$ in whole soil layer at 82 and $102 \mathrm{DAE}$, respectively. Under $\mathrm{H}_{40}$ condition, the NR activity increased by $17.8,23.1,48.0$, and $67.2 \%$ in CK compared with $\mathrm{W}_{75} \mathrm{~N}_{1}, \mathrm{~W}_{75} \mathrm{~N}_{0}, \mathrm{~W}_{55} \mathrm{~N}_{1}$, and $\mathrm{W}_{55} \mathrm{~N}_{0}$ in whole soil layer at 82 and $102 \mathrm{DAE}$, respectively.

\section{The Relationship of Root with $\boldsymbol{F}_{\boldsymbol{v}} / \boldsymbol{F}_{\boldsymbol{m}}$, $\mathrm{Y}(\mathrm{II})$ and $g_{\mathrm{s}}$}

The correlation analysis (Table 3 ) showed that the cotton root NR activity was negatively related $(P<0.01)$ to MDA and was positively related to $F_{v} / F_{m}(P<0.01)$, PSII $(P<0.01)$, total chlorophyll $(P<0.05)$ and $g_{\mathrm{s}}(P<0.01)$. The MDA was negatively associated $(P<0.01)$ with $F_{v} / F_{m}$, PSII and total chlorophyll content. The RLD significantly positively $(P<0.05)$ related to $g_{s}$. Moreover, the $F_{v} / F_{m}$ positively related to PSII $(P<0.01)$, total chlorophyll $(P<0.01)$ and $g_{\mathrm{s}}(P<0.05)$. These finding implied that improving the root activity and root length contributed to enhanced leaf photosynthesis.

\section{DISCUSSION}

In modern agricultural systems, water-nutrient management are cotton yield increment technologies especially in arid climatic conditions. The main objective of this study was to determine the effects of irrigation and nitrogen management under different soil depth on cotton crop physiological attributes. In the present study, $\mathrm{H}_{20} \mathrm{~W}_{75} \mathrm{~N}_{1}$ increased photosynthate accumulation of aerial part of cotton plant that promoted the allocation of assimilates toward reproductive organs. While the assimilate formation is closely related with root system [root distribution and physiological activity (root vigor and root NR)] and photosystem (light capturing organ, the activity of PSII reactive center and the utilization or consumption of photochemical energy). However, the root system and leaf photosystem act together to promote water-nutrient use efficiency and achieve optimal yield.

Higher root distribution vigor and NR are dependent on water and $\mathrm{N}$ absorption (Luo et al., 2015; Gao and Lynch, 2016). In addition, water- $\mathrm{N}$ application can also affect root growth or distribution (Jackson et al., 1990; Wasson et al., 2012). We found that $\mathrm{H}_{20} \mathrm{~W}_{75} \mathrm{~N}_{1}$ increased root diameter resulted in the development of effective roots (diameter less than $0.05 \mathrm{~mm}$ ) to efficiently uptake and transport. This protected the integrity of the lipid membrane in the root and enhanced root stress tolerance in the $0-80 \mathrm{~cm}$ soil layers at 82 and $102 \mathrm{DAE}$. A possible reason was that $\mathrm{H}_{20} \mathrm{~W}_{75} \mathrm{~N}_{1}$ increased the available water- $\mathrm{N}$ in the soil layer, while higher available water-N also promoted the NR content and the root protective enzyme which resulted in more efficient water and $\mathrm{N}$ uptake (Jackson et al., 1990). $\mathrm{H}_{20} \mathrm{~W}_{75} \mathrm{~N}_{1}$ combination increased antioxidant enzymes content which resulted in lower ROS production in the cotton roots, and higher water-N uptake. Our data is consistent with Medici et al. (2004) and Reddy et al. (2004), which suggested that higher available water- $\mathrm{N}$ avoided the water- $\mathrm{N}$ stress that causes ROS production in the root.

Application of water- $\mathrm{N}$ initially contacts with the root system which in turn affects photosynthesis through root system activity.
We observed that total chlorophyll had a positive relationship with the NR in the roots. In contrast, NR activity had a significantly negative relationship with MDA content. This indicated that the chlorophyll in leaf was closely associated to $\mathrm{N}$ uptake. This might be due to $\mathrm{H}_{20} \mathrm{~W}_{75} \mathrm{~N}_{1}$ resulting in increased available water and $\mathrm{N}$ in the soil and decreased the transportation resistance to water-nutrient in roots (Segal et al., 2008; Wasson et al., 2012). Concurrently, inducing NR generation further promoted $\mathrm{N}$ absorption and transportation to the aerial parts of the cotton plant (Lilley and Kirkegaard, 2011; Hunter and Ruffner, 2015) prior to 82 DAE. More $\mathrm{N}$ accumulation in leaf enhanced chlorophyll formation and conversion into chlorophyll under light conditions (Benli et al., 1991; Armstrong et al., 1995). Furthermore, antioxidants enzymes activity was increased in the leaf prior to $82 \mathrm{DAE}$ and decreased the accumulation of ROS which in turn retarded in the decomposition of the Chl $a$ and $b$ (Nagata et al., 2005). Our data is inconsistent with the previous research that available water- $\mathrm{N}$ in the soil and $\mathrm{N}$ content in the leaf did not affect the sorghum crop leaf chlorophyll content (Zhao et al., 2005). The soil properties could have caused lower available water- $\mathrm{N}$ in the soil profile. Thus, $\mathrm{H}_{20} \mathrm{~W}_{75} \mathrm{~N}_{1}$ combination enhanced water and $\mathrm{N}$ as well as the activity of enzymes, which promoted the formation of chlorophyll in leaves prior to 82 DAE.

Measurements of $\mathrm{Y}(\mathrm{II})$ provide a rapid method to determine the PSII operating efficiency under different light and environmental conditions (Baker, 2008). In the present study, greater value of $\mathrm{Y}$ (II) in different treatments were observed at 62 or $72 \mathrm{DAE}$, which are considered the most vigorous growth stages of cotton (Yi et al., 2014). The ratios of Y(II) and $P_{\mathrm{n}}$ was also increased significantly because the $Y($ II) was increased more quickly than $P_{\mathrm{n}}$. This increment was accompanied by an increase in the levels of antioxidants and activities of enzymes involved in scavenging ROS led to higher electron flux to oxygen and promoted $\mathrm{CO}_{2}$ assimilation. Several researchers also showed similar phenomenon (Fryer et al., 1998; Farage et al., 2006; Baker, 2008). Leaf Pro, CAT, POD, and SOD were increased in $\mathrm{H}_{20} \mathrm{~W}_{75} \mathrm{~N}_{1}$ prior to $82 \mathrm{DAE}$. This increment might be due to the enhanced leaf physiological activity which promoted the antioxidant activity and decreased ROS production and lipid membrane peroxidation. This resulted in higher chlorophyll content and avoided photo inhibition leading to higher PSII activity (Nishiyama et al., 2006; Gill and Tuteja, 2010). Moreover, $F_{v} / F_{m}$ was linearly associated with total chlorophyll which indicates the activity of PSII had a positive relationship with available water-nutrient. Results imply that $\mathrm{H}_{20} \mathrm{~W}_{75} \mathrm{~N}_{1}$ enhanced activity of the reaction centers of PSII and the photo protective mechanism of PSII, which promoted photochemical energy conversion and the ETR of PSII prior to 82 DAE. A possible reason might be due to water soluble-nutrient application which also promoted the root absorptive capacity and led to higher leaf $\mathrm{N}$ accumulation. This increment in $\mathrm{N}$ accumulation contributed to higher $\mathrm{Chl} a$ and $b$ contents prior to $82 \mathrm{DAE}$ (Jeon et al., 2006). On the other hand, relative higher root growth activity ensured higher water soluble-N uptake (Segal et al., 2008; Wasson et al., 2012). This decreased the photo inhibition of PSII and promoted the photochemical efficiency and the 
ETR of PSII (Jia et al., 2008; Hayashi et al., 2013; Luo et al., 2016).

The higher activity of the reaction center of photosystems drives chemical energy storage and promotes the regeneration of RuBP which led to higher $P_{\mathrm{n}}$ (Hendrickson et al., 2004; Takahashi et al., 2013). The $P_{\mathrm{n}}$ showed strong responses to water and N supply (Flexas et al., 2006b; Makoto and Koike, 2007). In this study the $P_{\mathrm{n}}$ was at peak under $\mathrm{H}_{20} \mathrm{~W}_{75} \mathrm{~N}_{1}$ application which was attributed to higher protective enzyme content and $\mathrm{NR}$ activity in the roots occasioned by efficient water solublenutrient uptake. In addition, more available water- $\mathrm{N}$ enhanced absorption and accumulation of $\mathrm{NO}_{3}{ }^{-}, \mathrm{NH}_{4}{ }^{+}, \mathrm{K}^{+}$in the root or leaf has led to efficient water uptake (Lopes and Araus, 2006). Water-N supply decreases water soluble-nutrient stress causing root-sourced signal (ABA), leading to stomatal opening and increased leaf water potential (Siddique et al., 1990; Tardieu and Davis, 1993) and physiological activity in leaves (Blum and Johnson, 1993). We also observed that, $\mathrm{H}_{20} \mathrm{~W}_{75} \mathrm{~N}_{1}$ still maintained a greater $P_{\mathrm{n}}$, and the leaves had begun to decrease the regulatory ability of the stomata. A possible reason was that the leaf senescence caused a lower regulatory ability in the stomata and had a direct thermodynamic effect when the leaf was exposed to higher temperature (about $38 \pm 2^{\circ} \mathrm{C}$ ) (Guo et al., 2006). Thus, $\mathrm{H}_{20} \mathrm{~W}_{75} \mathrm{~N}_{1}$ increased root $\mathrm{NR}$ and protective enzyme, enhanced water-nutrient uptake and ultimately improved $g_{\mathrm{s}}$ which increased leaf gas exchange attributes and $\mathrm{CO}_{2}$ fixing prior to 82 DAE.

Interestingly, the $\mathrm{H}_{20} \mathrm{~W}_{75} \mathrm{~N}_{1}$ increased root physiological activity by $7.0-40.1 \%$ in $0-80 \mathrm{~cm}$ soil profile at 82 and 102 DAE. This increased water-N uptake and light absorption and utilization as well the activity of the reaction centers of PSII that contributed to photosynthate production (Reddy et al., 2004; Takahashi et al., 2013). Decreased root distribution under adequate water-nutrient application can decrease root dry matter and increase plant aerial parts dry matter accumulation of cotton crops (Ekmekçi et al., 2008). Available water-nutrient could promote accumulation of leaf dry matter which contributes to higher photosynthesis (Ekmekçi et al., 2008; Yang et al., 2011b). Water-nutrient application could increase available waternutrient in the soil (Pettigrew, 2004), and enhance transport

\section{REFERENCES}

Aragüés, L., Faci, G., Martínez-Cob, A., and Medina, P. (2014). Effects of deficit irrigation strategies on soil salinization and sodification in a semiarid dripirrigated peach orchard. Agric. Water Manag. 142, 1-9. doi: 10.1016/j.agwat. 2014.04.004

Armstrong, G. A., Runge, S., Frick, G., Sperling, U., and Apel, K. (1995). Identification of NADPH: protochlorophyllide oxidoreductases $\mathrm{A}$ and B: a branched pathway for light-dependent chlorophyll biosynthesis in Arabidopsis thaliana. Plant Physiol. 108, 1505-1517. doi: 10.1104/pp.108.4. 1505

Arnon, D. (1949). Measuring chlorophyll and anthocyanin concentration. Plant Physiol. 24, 1-15. doi: 10.1104/pp.24.1.1

Asada, K. (1999). THE WATER-WATER CYCLE IN CHLOROPLASTS: scavenging of active oxygens and dissipation of excess photons. Annu. Rev. Plant Physiol. Plant Mol. Biol. 50, 601-639. doi: 10.1146/annurev.arplant.50. 1.601

Bailly, C., Benamar, A., Corbineau, F., and Dome, D. (1996). Changes in malondialdehyde contents and in superoxide dismutase, catalase, of assimilates from source to sink, which promote dry matter accumulation in reproductive structures (Radin et al., 1992; Pettigrew, 2004). Our data showed that $\mathrm{H}_{20} \mathrm{~W}_{75} \mathrm{~N}_{1}$ enhanced the biomass accumulation and allocation into reproductive organs, but decreased partitioning to roots.

\section{CONCLUSION}

The presents study demonstrated that irrigation and $\mathrm{N}$-fertilization managements significantly improved cotton plants morphological and physiological attributes under different water depths. $\mathrm{H}_{20} \mathrm{~W}_{75} \mathrm{~N}_{1}$ enhanced root physiological activity and simultaneously promoted the capacity of light capture (photosynthetic pigment) and conversion efficiency of photochemical energy, the utilization of light energy before full boll stage, and maintained leaf gas exchange parameters by relieving the adverse effects on roots after full boll stage. This improved dry mass accumulation in aerial parts and allocation into reproductive organs. Root physiological activity was positively correlated with chlorophyll, $F_{v} / F_{m}, \mathrm{Y}(\mathrm{II})$, and $g_{\mathrm{s}}$. Therefore, use of shallow irrigation with moderate water and nitrogen application is an effective strategy for optimal biomass accumulation and cotton yield.

\section{AUTHOR CONTRIBUTIONS}

HL initiated and designed the experiment. XT performed the experiments and collected the data. ZC analyzed the data and wrote the manuscript. DT, AK, and $\mathrm{HL}$ revised the manuscript.

\section{ACKNOWLEDGMENTS}

We are thankful to funding by the National Natural Science Foundation of China (Grant No. 31760355) and the Fok Ying Tung Education Foundation (Grant No. 15030).

glutathione reductase activities in sunflower seeds related to accelerated seed aging. Plant Physiol. 97, 104-110. doi: 10.1111/j.1399-3054.1996.tb0 0485.x

Baker, N. R. (2008). Chlorophyll fluorescence: a probe of photosynthesis in vivo. Annu. Rev. Plant Biol. 59, 89-113. doi: 10.1146/annurev.arplant.59.032607. 092759

Bates, L. S., Waldren, R. P., and Teare, I. D. (1973). Rapid determination of free proline for water stress studies. Plant Soil 39, 205-207. doi: 10.1016/j.dental. 2010.07.006

Benli, M., Schulz, R., and Apel, K. (1991). Effect of light on the NADPHprotochlorophyllide oxidoreductase of Arabidopsis thaliana. Plant Mol. Biol. 16, 615-625. doi: 10.1007/BF00023426

Bilger, W., and Björkman, O. (1990). Role of the xanthophyll cycle in photoprotection elucidated by measurements of light-induced absorbance changes, fluorescence and photosynthesis in leaves of Hedera canariensis. Photosynth. Res. 25, 173-185. doi: 10.1007/BF00033159

Björkman, O., and Demmig, B. (1987). Photon yield of $\mathrm{O}_{2}$ evolution and chlorophyll fluorescence characteristics at $77 \mathrm{k}$ among vascular plants of diverse origins. Planta 170, 489-504. doi: 10.1007/BF00402983 
Blum, A. (2005). Drought resistance, water-use efficiency, and yield potential: are they compatible, dissonant, or mutually exclusive? Aust. J. Agric. Res. 56, 1159-1168. doi: 10.1071/AR05069

Blum, A., and Johnson, J. W. (1993). Wheat cultivars respond differently to a drying top soil and a possible non-hydraulic root signal. J. Exp. Bot. 44, 1149-1153. doi: $10.1093 / \mathrm{jxb} / 44.7 .1149$

Cakmak, I., and Marschner, H. (1992). Magnesium deficiency and high light intensity enhance activities of superoxide dismutase, ascorbate peroxidase, and glutathione reductase in bean leaves. Plant Physiol. 98, 1222-1227. doi: 10.1104/ pp.98.4.1222

China Cotton Fair Examination (2012/2013). Available at: http://www.ccqsc.gov. $\mathrm{cn} /$ cotton/index.jsp

Einsmann, J. C., Jones, R. H., Pu, M., and Mitchell, A. J. (1999). Nutrient foraging traits in 10 co-occurring plant species of contrasting life forms. J. Ecol. 87, 609-619. doi: 10.1046/j.1365-2745.1999.00376.x

Ekmekçi, Y., Tanyolac, D., and Ayhan, B. (2008). Effects of cadmium on antioxidant enzyme and photosynthetic activities in leaves of two maize cultivars. J. Plant Physiol. 165, 600-611. doi: 10.1016/j.jplph.2007. 01.017

Elvira, G. L., Rafael, J. L. B., and Luis, L. B. (2004). Effect of $\mathrm{N}$ rate, timing and splitting and $\mathrm{N}$ type on bread-making quality in hard red spring wheat under rainfed Mediterranean conditions. Field Crops Res. 85, 213-236. doi: 10.1016/ S0378-4290(03)00167-9

Evans, J. R. (1989). Photosynthesis and nitrogen relationships in leaves of $\mathrm{C}_{3}$ plants. Oecologia 78, 9-19. doi: 10.1007/BF00377192

Farage, P. K., Blowers, D., Long, S. P., and Baker, N. R. (2006). Low growth temperatures modify the efficiency of light use by photosystem II for $\mathrm{CO}_{2}$ assimilation in leaves of two chilling-tolerant $\mathrm{C}_{4}$ species, Cyperus longus $\mathrm{L}$. and Miscanthus $x$ giganteus. Plant Cell Environ. 29, 720-728. doi: 10.1111/j.13653040.2005.01460.x

Farooq, M., Wahid, A., Kobayashi, N., Fujita, D., and Basra, S. M. A. (2009). "Plant drought stress: effects, mechanisms and management," in Sustainable Agriculture, eds E. Lichtfouse, M. Navarrete, P. Debaeke, V. Souchere, and C. Alberola (Dordrecht: Springer), 153-188.

Flexas, J., Bota, J., Galmes, J., Medrano, H., and Ribas, C. (2006a). Keeping a positive carbon balance under adverse conditions: responses of photosynthesis and respiration to water stress. Physiol. Plant. 127, 343-352. doi: 10.1111/j. 1399-3054.2006.00621.x

Flexas, J., Ribas, C. M., Bota, J., Galmés, J., Henkle, M., Martínez, C., et al. (2006b). Decreased Rubisco activity during water stress is not induced by decreased relative water content but related to conditions of low stomatal conductance and chloroplast $\mathrm{CO}_{2}$ concentration. New Phytol. 172, 73-82. doi: 10.1111/j. 1469-8137.2006.01794.x

Fryer, M. J., Andrews, J. R., Oxborough, K., Blowers, D. A., and Baker, N. R. (1998). Correction: relationship between $\mathrm{CO} 2$ assimilation, photosynthetic electron transport, and active $\mathrm{O} 2$ metabolism in leaves of maize in the field during periods of low temperature. Plant Physiol. 116, 571-581. doi: 10.1104/pp.116. 2.571

Gao, Y., and Lynch, J. P. (2016). Reduced crown root number improves water acquisition under water deficit stress in maize (Zea mays L.). J. Exp. Bot. 67, 4545-4557. doi: 10.1093/jxb/erw243

Genty, B., Briantais, J. M., and Baker, N. R. (1989). The relationship between the quantum yield of photosynthetic electron transport and quenching of chlorophyll fluorescence. Biochim. Biophys. Acta 990, 87-92. doi: 10.1016/ S0304-4165(89)80016-9

Gill, S. S., and Tuteja, N. (2010). Reactive oxygen species and antioxidant machinery in abiotic stress tolerance in crop plants. Plant Physiol. Biochem. 48, 909-930. doi: 10.1016/j.plaphy.2010.08.016

Guo, Y. P., Zhou, H. F., and Zhang, L. C. (2006). Photosynthetic characteristics and protective mechanisms against photooxidation during high temperature stress in two citrus species. Sci. Hortic. 108, 260-267. doi: 10.1016/j.scienta.2006. 01.029

Gwenzi, W., Veneklaas, E. J., Holmes, K. W., Bleby, T. M., Phillips, I. R., and Hinz, C. (2011). Spatial analysis of fine root distribution on a recently constructed ecosystem in a water-limited environment. Plant Soil 344, 255-272. doi: 10.1007/s11104-011-0744-8

Hayashi, M., Hayashi, T., Kuno, C., Tani, T., Endo, I., Higashino, A., et al. (2013). Enhanced nitrogen uptake and photosynthesis of rice grown with deep and permanent irrigation method: possible mechanism for chalky grain reduction. Plant Prod. Sci. 16, 309-316. doi: 10.1626/pps.16.309

Hendrickson, L., Furbank, R. T., and Chow, W. S. (2004). A simple alternative approach to assessing the fate of absorbed light energy using chlorophyll fluorescence. Photosynth. Res. 82, 73-81. doi: 10.1023/B:PRES.0000040446. 87305.f4

Hoorn, J. W., Katerji, N., Hamdy, A., and Mastrorilli, M. (1993). Effect of saline water on soil salinity and on water stress, growth, and yield of wheat and potatoes. Agric. Water Manag. 23, 247-265. doi: 10.1016/0378-3774(93) 90032-6

Hu, T., Kang, S., Li, F., and Zhang, J. (2011). Effects of partial root-zone irrigation on hydraulic conductivity in the soil-root system of maize plants. J. Exp. Bot. 62, 4163-4172. doi: 10.1093/jxb/err110

Hunter, J. J., and Ruffner, H. P. (2015). Diurnal and seasonal changes in nitrate reductase activity and nitrogen content of grapevines: effect of canopy management. Vitis 36, 1-6.

Hura, T., Hura, K., Grzesiak, M., and Rzepka, A. (2007). Effect of long-term drought stress on leaf gas exchange and fluorescence parameters in $\mathrm{C}_{3}$ and $\mathrm{C}_{4}$ plants. Acta Physiol. Plant. 29, 103-113. doi: 10.1007/s11738-006-0013-2

Jackson, R. B., Manwaring, J. H., and Caldwell, M. M. (1990). Rapid physiological adjustment of root to localized soil enrichment. Nature 344, 58-60. doi: 10.1038/ 344058a0

Jeon, M. W., Ali, M. B., Hahn, E. J., and Paek, K. Y. (2006). Photosynthetic pigments, morphology and leaf gas exchange during ex-vitro acclimatization of micropropagated CAM Doritaenopsis plantlets under relative humidity and air temperature. Environ. Exp. Bot. 55, 183-194. doi: 10.1016/j.envexpbot.2004. 10.014

Jia, H., Oguchi, R., Hope, A. B., Barber, J., and Chow, W. S. (2008). Differential effects of severe water stress on linear and cyclic electron fluxes through photosystem I in spinach leaf discs in $\mathrm{CO}_{2}$-enriched air. Planta 228, 803-812. doi: 10.1007/s00425-008-0783-4

Khan, A., Najeeb, U., Wang, L., Tan, D. K. Y., Yang, G., and Munsif, F. (2017). Planting density and sowing date strongly influence growth and lint yield of cotton crops. Field Crops Res. 209, 129-135. doi: 10.1016/j.fcr.2017.04.019

Krall, J. P., and Edwards, G. E. (1992). Relationship between photosystem ii activity and $\mathrm{CO}_{2}$, fixation in leaves. Physiol. Plant. 86, 180-187. doi: 10.1111/j.13993054.1992.tb01328.x

Krause, G. H., and Weis, E. (1991). Chlorophyll fluorescence and photosynthesis: the basics. Annu. Rev. Plant Biol. 42, 313-349. doi: 10.1007/978-1-61779237-3_16

Ladjal, M., Epron, D., and Ducrey, M. (2000). Effects of drought preconditioning on thermotolerance of photosystem II and susceptibility of photosynthesis to heat stress in cedar seedlings. Tree Physiol. 20, 1235-1241. doi: 10.1093/ treephys/20.18.1235

Lawlor, D. W., and Cornic, G. (2002). Photosynthetic carbon assimilation and associated metabolism in relation to water deficits in higher plants. Plant Cell Environ. 25, 275-294. doi: 10.1046/j.0016-8025.2001.00814.x

Leiwen, J. (2005). Water resources, land exploration and population dynamics in arid areas-the case of the Tarim River basin in Xinjiang of China. Popul. Environ. 26, 471-503. doi: 10.1007/s11111-005-0008-8

Lichtenthaler, H. K. (1996). Vegetation stress: an introduction to the stress concept in plants. J. Plant Physiol. 148, 4-14. doi: 10.1016/S0176-1617(96)80287-2

Lilley, J. M., and Kirkegaard, J. A. (2011). Benefits of increased soil exploration by wheat roots. Field Crops Res. 122, 118-130. doi: 10.1016/j.fcr.2011. 03.010

Lopes, M. S., and Araus, J. L. (2006). Nitrogen source and water regime effects on durum wheat photosynthesis and stable carbon and nitrogen isotope composition. Plant Physiol. 126, 435-445. doi: 10.1111/j.1399-3054.2006. 00595.x

Loveys, B. R., Stoll, M., and McCarthy, M. G. (2000). Using plant physiology to improve the water use efficiency of horticultural crops. Acta Hortic. 537, 187-197. doi: 10.17660/ActaHortic.2000.537.19

Luo, H. H., Tao, X. P., Hu, Y. Y., Zhang, Y. L., and Zhang, W. F. (2015). Response of cotton root growth and yield to root restriction under various water and nitrogen regimes. J. Plant Nutr. Soil Sci. 178, 384-392. doi: 10.1002/jpln. 201400264

Luo, H. H., Zhang, H. Z., Han, H. Y., Hu, Y. Y., Zhang, Y. L., and Zhang, W. F. (2014). Effects of water storage in deeper soil layers on growth, yield, and water 
productivity of cotton (Gossypium hirsutum L.) in arid areas of northwestern China. Irrig. Drain. 63, 59-70. doi: 10.1002/ird.1793

Luo, H. H., Zhang, Y. L., and Zhang, W. F. (2016). Effects of water stress and rewatering on photosynthesis, root activity, and yield of cotton with drip irrigation under mulch. Photosynthetica 54, 65-73. doi: 10.1007/s11099-0150165-7

Makoto, K., and Koike, T. (2007). Effects of nitrogen supply on photosynthetic and anatomical changes in current-year needles of Pinus koraiensis seedlings grown under two irradiances. Photosynthetica 45, 99-104. doi: 10.1007/s11099-0070015-3

Medici, L. O., Azevedo, R. A., Smith, R. J., and Lea, P. J. (2004). The influence of nitrogen supply on antioxidant enzymes in plant roots. Funct. Plant Biol. 31, 1-9. doi: 10.1071/FP03130

Nagata, N., Tanaka, R., and Satoh, S. (2005). Identification of a vinyl reductase gene for chlorophyll synthesis in Arabidopsis thaliana and implications for the evolution of Prochlorococcus species. Plant Cell 17, 233-240. doi: 10.1105/tpc. 104.027276

Ndabamenye, T., Blomme, G., Vanlauwe, B., Uzayisenga, B., and Annandale, J. G. (2013). Nutrient imbalance and yield limiting factors of low input East African highland banana (Musa spp. AAA-EA) cropping systems. Field Crops Res. 147, 68-78. doi: 10.1016/j.fcr.2013.04.001

Nishiyama, Y., Allakhverdiev, S. I., and Murata, N. (2006). A new paradigm for the action of reactive oxygen species in the photoinhibition of photosystem II. Biochim. Biophys. Acta 1757, 742-749. doi: 10.1016/j.bbabio.2006.05.013

Oxborough, K., and Baker, N. R. (1997). Resolving chlorophyll a fluorescence images of photosynthetic efficiency into photochemical and nonphotochemical components-calculation of $\mathrm{qP}$ and $\mathrm{Fv} / \mathrm{Fm}$ without measuring Fo. Photosynth. Res. 54, 135-142. doi: 10.1023/A:1005936823310

Pettigrew, W. T. (2004). Physiological consequences of moisture deficit stress in cotton. Crop Sci. 44, 1265-1272. doi: 10.2135/cropsci2004.1265

Radin, J. W. (1974). Distribution and development of nitrate reductase activity in germinating cotton seedlings. Plant Physiol. 53, 458-463. doi: 10.1104/pp.53. 3.458

Radin, J. W., Reaves, L. L., and Mauney, J. R. (1992). Yield enhancement in cotton by frequent irrigations during fruiting. Agron. J. 84, 551-557. doi: 10.2134/ agronj1992.00021962008400040002x

Raines, C. A. (2011). Increasing photosynthetic carbon assimilation in $C_{3}$ plant to improve crop yield: current and future strategies. Plant Physiol. 155, 36-42. doi: 10.1104/pp.110.168559

Reddy, A. R., Chaitanya, K. V., and Vivekanandan, M. (2004). Droughtinduced responses of photosynthesis and antioxidant metabolism in higher plants. J. Plant Physiol. 161, 1189-1202. doi: 10.1016/j.jplph.2004. 01.013

Schultz, H. R. (1996). Leaf absorptance of visible radiation in Vitis vinifera L. estimates of age and shade effects with a simple field method. Sci. Hortic. 66, 93-102. doi: 10.1016/0304-4238(96)00876-X

Segal, E., Kushnir, T., Mualem, Y., and Shani, U. (2008). Water uptake and hydraulics of the root hair rhizosphere. Vadose Zone J. 7, 1027-1034. doi: $10.2136 /$ vzj2007.0122

Siddique, K. H. M., Belford, R. K., and Tennant, D. (1990). Root: shoot ratios of old and modern, tall and semi-dwarf wheat in a Mediterranean environment. Plant Soil 121, 89-98. doi: 10.1007/BF00013101

Takahashi, H., Clowez, S., and Wollman, F. A. (2013). Cyclic electron flow is redox-controlled but independent of state transition. Nat. Commun. 4:1954. doi: $10.1038 /$ ncomms 2954

Tardieu, F., and Davis, W. J. (1993). Integration of hydraulic and chemical signaling in the control of stomatal conductance and water status of droughted plants. Plant Cell Environ. 16, 341-349. doi: 10.1111/j.1365-3040.1993. tb00880.x
Tezara, W., Mitchell, V. J., and Driscoll, S. D. (1999). Water stress inhibits plant photosynthesis by decreasing coupling factor and ATP. Nature 401, 914-917. doi: $10.1038 / 44842$

Vitousek, P. M., Aber, J. D., and Howarth, R. W. (1997). Human alteration of the global nitrogen cycle: sources and consequences. Ecol. Appl. 7, 737-750. doi: 10.1890/1051-0761(1997)007[0737:HAOTGN]2.0.CO;2

Wang, J., Xu, C., Gao, S., Han, X., and Ju, D. (2013). Effects of water and nitrogen utilized by means of dripping on growth of root and canopy and matter distribution in spring wheat. Adv. J. Food Sci. Technol. 5, 474-481. doi: 10.19026/ajfst.5.3294

Wasson, A. P., Richards, R. A., and Chatrath, R. (2012). Traits and selection strategies to improve root systems and water uptake in water-limited wheat crops. J. Exp. Bot. 63, 3485-3498. doi: 10.1093/jxb/ers111

Wu, H. X., Ma, Y. Z., and Xiao, J. P. (2013). Photosynthesis and root characteristics of rice (Oryza sativa L.) in floating culture. Photosynthetica 51, 231-237. doi: 10.1007/s11099-013-0015-4

Xu, T., Xin, L., Jian, C., Ze, Z., Xianghu, W., and Peng, Z. (2015). Effects of cotton soil moisture content, nitrate nitrogen distribution and yield by different fertigation strategies. Cotton Sci. 27, 329-336.

Yahdjian, L., Gherardi, L., and Sala, O. E. (2011). Nitrogen limitation in aridsubhumid ecosystems: a meta-analysis of fertilization studies. J. Arid Environ. 75, 675-680. doi: 10.1016/j.jaridenv.2011.03.003

Yang, G., Tang, H., and Nie, Y. (2011a). Responses of cotton growth, yield, and biomass to nitrogen split application ratio. Eur. J. Agron. 35, 164-170. doi: 10.1016/j.eja.2011.06.001

Yang, G., Tang, H., Tong, J., Nie, Y., and Zhang, X. (2011b). Effect of fertilization frequency on cotton yield and biomass accumulation. Field Crops Res. 125, 161-166. doi: 10.1016/j.fcr.2011.08.008

Yi, X. P., Zhang, Y. L., Yao, H. S., and Zhang, W. F. (2016). Rapid recovery of photosynthetic rate following soil water deficit and re-watering in cotton plants (Gossypium herbaceum L.) is related to the stability of the photosystems. Plant Physiol. 194, 23-34. doi: 10.1016/j.jplph.2016.01.016

Yi, X. P., Zhang, Y. L., Yao, H. S., Zhang, X. J., Luo, H. H., Gou, L., et al. (2014). Alternative electron sinks are crucial for conferring photoprotection in fieldgrown cotton under water deficit during flowering and boll setting stages. Funct. Plant Biol. 41, 737-747. doi: 10.1071/FP13269

Zhang, H., Khan, A., Tan, D. K. Y., and Luo, H. (2017). Rational water and nitrogen management improves root growth, increases yield and maintains water use efficiency of cotton under mulch drip irrigation. Front. Plant Sci. 8:912. doi: $10.3389 /$ fpls.2017.00912

Zhao, D., Reddy, K. R., and Kakani, V. G. (2005). Nitrogen deficiency effects on plant growth, leaf photosynthesis, and hyperspectral reflectance properties of sorghum. Eur. J. Agron. 22, 391-403. doi: 10.1016/j.eja.2004.06.005

Zheng, M., Tao, Y., Hussain, S., Jiang, Q., Peng, S., Huang, J., et al. (2016). Seed priming in dry direct-seeded rice: consequences for emergence, seedling growth and associated metabolic events under drought stress. Plant Growth Regul. 78, 167-178. doi: 10.1007/s10725-015-0083-5

Conflict of Interest Statement: The authors declare that the research was conducted in the absence of any commercial or financial relationships that could be construed as a potential conflict of interest.

Copyright $\odot 2018$ Chen, Tao, Khan, Tan and Luo. This is an open-access article distributed under the terms of the Creative Commons Attribution License (CC BY). The use, distribution or reproduction in other forums is permitted, provided the original author(s) and the copyright owner are credited and that the original publication in this journal is cited, in accordance with accepted academic practice. No use, distribution or reproduction is permitted which does not comply with these terms. 